\title{
Changes in Neighborhood Inequality, 2000-2010
}

\author{
by \\ Daniel H. Weinberg \\ Biocomplexity Institute of Virginia Tech
}

\section{CES 16-18 March, 2016}

The research program of the Center for Economic Studies (CES) produces a wide range of economic analyses to improve the statistical programs of the U.S. Census Bureau. Many of these analyses take the form of CES research papers. The papers have not undergone the review accorded Census Bureau publications and no endorsement should be inferred. Any opinions and conclusions expressed herein are those of the author(s) and do not necessarily represent the views of the U.S. Census Bureau. All results have been reviewed to ensure that no confidential information is disclosed. Republication in whole or part must be cleared with the authors.

To obtain information about the series, see www.census.gov/ces or contact Fariha Kamal, Editor, Discussion Papers, U.S. Census Bureau, Center for Economic Studies 2K132B, 4600 Silver Hill Road, Washington, DC 20233, CES.Papers.List@census.gov. To subscribe to the series, please click here. 


\begin{abstract}
Recent work has suggested that higher income inequality may be a desirable attribute of a neighborhood in that it represents diversity, even though high (and rising) inequality appears to be detrimental to the nation as a whole. The research reported here has determined the key characteristics of a census tract that are associated with the level of inequality in 2000 or 2010, and those associated with changes in income inequality between 2000 and 2010. For the change, the strongest influence is a negative effect for the level of income inequality in 2000; that is, higher income inequality in 2000 leads to a decline over the decade, ceteris paribus. Neighborhoods with higher proportions or levels of the following population and housing characteristics tend to have both higher income inequality and a larger increase in income inequality between 2000 and 2010: individuals in poverty, those with a bachelor's degree, older individuals, householders living alone, and median rent, and lower median housing value and household income. Among these, perhaps the most important determinant is the percent in poverty in 2000. Furthermore, as the baseline level of demographic and economic diversity increases, the better the baseline and change characteristics explain the change in the Gini index from 2000 to 2010.
\end{abstract}

Keyword: Neighborhood, neighborhood succession, neighborhood dynamics, income inequality, Gini index

This work would not have been possible without stellar work by Kirk Davis and the late Marie Pees of the U.S. Census Bureau, who retabulated the 2000 Census long form (sample) data into 2010 census tract boundaries, and Ted Logotheti who provided the American Community Survey tabulation extracts. This work was performed at the Federal Research Data Center at the U.S. Census Bureau and I wish to thank its administrator, Danielle Sandler, for her help; all results have been reviewed by Amy Lauger to ensure that no confidential information is disclosed. Any opinions and conclusions expressed herein are those of the author and do not necessarily represent the views of the Census Bureau. I also acknowledge with thanks the comments and suggestions of Henry Pollakowski and Stephanie Shipp. Contact information: 2501 Lisbon Lane, Alexandria VA 22306; dhweinberg@gmail.com 


\section{CHANGES IN NEIGHBORHOOD INCOME INEQUALITY, 2000-2010}

\section{INTRODUCTION}

Where one lives can affect many aspects of well-being including access to education and employment (Temkin and Rohe 1996). And income inequality in that neighborhood can affect outcomes, including crime and health. ${ }^{1}$ There is a substantial literature examining neighborhood dynamics (also called neighborhood succession), mostly focusing on the housing market aspects of change over time (see Megbolugbe et al. 1996). ${ }^{2}$ Most of the research has focused on "downward" movement - the transition from neighborhoods from primarily high-income to primarily low-income (poor) occupants and "filtering" the change in the housing stock from high quality and newer housing to lower quality and older housing (Brueckner 1977; Weicher and Thibodeau 1988; Bond and Coulson 1989; Weicher et al. 2010). But some neighborhoods improve their housing quality over time, typically due to new construction, or considerable renovation (e.g., via "gentrification").

This paper focuses on a particular non-housing aspect of neighborhood change change in income inequality over a 10-year period, and how such change relates to both the initial conditions present in the neighborhood, and to changes in the sociodemographic and housing characteristics of the neighborhood over that period. ${ }^{3}$ If

\footnotetext{
${ }^{1}$ Freedman and McGavock (2015: 807) cite, among others, Hipp (2007) on the effects of inequality on crime, and Nkansah-Amankra et al. (2010) on effects on health.

${ }^{2}$ Grigsby et al. (1987) cite a literature on neighborhood succession dating back to the 1920s. 3 The two periods surveyed (2000, with questions about 1999 income, and 2008-2012, with questions about the previous 12 months of income) covered roughly similar periods of economic activity. According to the National Bureau of Economic Research's business cycle dating, there were recessions in March 2000 to November 2001, and December 2007 to J une 2009.
} 
indeed the neighborhood context of inequality matters, then how that inequality changes over time should matter as well. Understanding that change and its context would give us a better foundation for examining other changes over time at the neighborhood level, perhaps eventually shedding more light on issues of residential segregation and neighborhood resilience. How much income inequality is good for a nation, a metropolitan area, or a neighborhood is an open question more data analysis might help to address. As Chetty and Hendren (2015), among others, have argued, "neighborhoods matter". 4 The Gini index of household income inequality is but one measure of a neighborhood's character. Galster and Booza (2007) show the value of examining income distributions in more detail, identifying "bipolar" communities (those with a strong representation of both high- and low-income households) as worthy of attention.

After a literature review, the subsequent section describes the data in more detail. In the "Findings" section, I first investigate the demographic characteristics associated with higher or lower levels of income inequality, using both regression and factor analyses. Then, I examine the correlates of change, examining both base period (2000) census tract (neighborhood) characteristics and the change in those characteristics over the 2000-2010 period. These aspects will be examined for metropolitan areas as a whole, and for categories of such areas, and also for the 21 largest metropolitan areas. Finally, differences across individual metropolitan areas are examined. The final section presents some modest conclusions and suggestions for future research.

\section{LITERATURE REVIEW}

${ }^{4}$ See http://howhousingmatters.org/articles/neighborhoods-matter/. 
One key issue is how to define a neighborhood. Megbolugbe et al. (1996: 1787) offers some alternatives. Theoretical arguments can ensue about which definition is best, but most researchers adopt a definition that allows them to analyze existing data. In effect, in the United States researchers often define a neighborhood as equivalent to the smallest geographic unit for which a significant number of estimates are published on a regular basis by the U.S. Census Bureau -- a census tract. ${ }^{5}$ Census tracts are intended to be relatively homogenous along whatever characteristics are felt to be important (though they must be contiguous geographically), and typically have about 4,000 residents and 1,500 housing units.

Income can provide command over material resources but is not divided equally among households; an index of income inequality is one measure of that disparity. As the Organization of Economic Cooperation and Development (2014: 110) noted, some people consider high levels of income inequality to be morally undesirable, and others regard income inequality as harmful ("causing conflict, limiting co-operation or creating psychological and physical health stresses"). But Weinberg (2011: 1) argued that unalloyed condemnation of high income inequality is not appropriate when the unit of analysis is the neighborhood, reflecting instead a great deal of individual choice of whom to live amongst. He argued that diversity in incomes among neighbors can

\footnotetext{
${ }^{5}$ Census tracts are collections of block groups, which in turn are collections of census blocks. Each decennial census publishes limited data at the block and block group levels (primarily population counts by race and ethnicity); the American Community Survey publishes some estimates at the block group level but more at the census tract level. Census tracts are defined either by local government officials, sometimes with the help of local residents, or by the Census Bureau in the absence of local assistance. Census tract boundaries are adjusted each decade to correspond with growth or decline. Most often, of course, census tracts defined in growth areas are subdivided in later years to preserve over-time comparability.
} 
enhance the social environment. In effect, the market determines income inequality outcomes by neighborhood (Hardman and Ioannides 2004), affected by residential segregation (Iceland and Weinberg 2002; Reardon et al. 2015).

Most research in this area has focused on income level or poverty rates, often on low-income (poor) neighborhoods, and typically on just a single metropolitan area (Ellen and O’Regan 2008). However, recent work by Weinberg (2011), using the firstever release of estimates at the census-tract level from the American Community Survey, investigated income inequality at the neighborhood level. His analysis covered 61,358 census tracts with 50 or more household interviews in the 2005-2009 period. His paper showed that low income inequality was most likely the result of income sorting higher-income households choose to live apart from lower-income ones: "The most income-mixed areas (the ones with the highest income inequality) tend to be found in cities, with older housing on average, while the most income-segregated areas (the ones with the lowest income inequality) tend to be found in suburbs, with younger housing on average" [Weinberg 2011: 20].

However, errors might arise when doing longitudinal analysis with published data because tract boundaries change. Published data also fail to allow researchers to distinguish the demographic differences among parts of tracts when reconstructing consistent geographic boundaries. ${ }^{6}$ The research in this paper will correct these longitudinal data problems faced by Ellen and O’Regan (2008), Wei (2012), and Wei and Knox (2014) in defining neighborhoods because it is based on a confidential dataset constructed by the Census Bureau that allocates all 2000 Census long-form sample members to the correct 2010 census tract, based on the internal Census Bureau

${ }^{6}$ See http://www.s4.brown.edu/ us2010/Researcher/Bridging.htm. 
geocoding, rather than using areal interpolation. ${ }^{7}$ Also, the database uses 2008-2012 ACS data files to represent average 2010 characteristics.

The focus of the proposed research will however be on just one neighborhood characteristic of well-being - change in household income inequality, as measured by the Gini index of inequality, for neighborhoods defined as census tract by the 2010 Census. The Gini index ranges from 0.0 , when all households have equal shares of income, to 1.0, when one household has all the income and the rest none. ${ }^{8}$

\section{DATA}

In order to simplify the 2010 Census and provide more frequent estimates for small areas and groups, the Census Bureau began the American Community Survey (ACS) to replace the Census long form, last fielded in 2000 to a 1-in-6 sample of households. After a decade of testing, the ACS was begun in 2005 and questionnaires were sent to a sample of about 2.9 million housing units each year, increased to 3.3 million in 2011. From 2005 to 2010, interviews were completed in the U.S. and Puerto Rico at about 1.9 million housing units each year, increasing to 2.1 million housing units in 2011. Five years of data (approximately an 11 percent sample) are cumulated to provide detailed information for small geographic areas (e.g., census tracts or small

\footnotetext{
${ }^{7}$ These data are available at Federal Statistical Research Data Centers to qualified researchers (see http:// www.census.gov/ces/rdcresearch/).

${ }^{8}$ For more information on measurement of income in the American Community Survey and on the Gini index of inequality, see Bishaw and Semega (2008). Weinberg (2011) also used two additional measures of income inequality - the ratio of the household income at the $90^{\text {th }}$ ( $95^{\text {th }}$ ) percentile to that of the household at the $10^{\text {th }}\left(20^{\text {th }}\right)$ percentile - and found that his results did not differ qualitatively from those found for the Gini index.
} 
towns) and for small population groups (e.g., those under 18 with a disability in a particular metropolitan or micropolitan area). Small jurisdictions are sampled at higher rates than larger ones. The 5 years of ACS data that are used in this study cover 2008 through 2012; for convenience they are referred to below as 2010 data (because the 5 years are centered on that date).

I used judgment to select the census tract characteristics to be included as potential explanatory variables. ${ }^{9}$ Appendix Table A. 1 shows the means and $25^{\text {th }}, 50^{\text {th }}$, and 75 $5^{\text {th }}$ percentiles for the Gini index and for all independent variables at the tract level, for 2000, 2008-2012, and the change from 2000 to 2008-2012. More than half of tracts had an increase in their Gini index over the decade, but this increase was concentrated at the bottom of the distribution (the Gini index at the $75^{\text {th }}$ percentile was the same at the beginning and end of the period).

Multi-collinearity is to be expected, as several variables are closely related to one another. For example, the total tract population and the total number of housing units in a tract are correlated at 0.83 , and the percent non-Hispanic White and the percent Black or African American are correlated at -0.68. Thus, the importance of particular variables must be inferred from the patterns of results, rather than from specific regressions. On the other hand, there are only three independent variables that are correlated with the change in the Gini index of income inequality from 2000 to 2010 at above the 0.20 level - the percent with less than a high school education, the percent in

\footnotetext{
${ }^{9}$ There is only one characteristic which is not comparable between the two surveys. The 2000 Census long form asked about moving in the past 5 years, while the ACS asks about moving in the past year. For that reason, the mobility variable is omitted from the change regressions.
} 
poverty, and household median income - and only one change variable has a correlation above 0.20 - change in the percent in poverty.

To be included in the analysis sample, tracts must have sufficient sample size in both the census in 2000 and the ACS in 2008-2012, and be in a metropolitan area. To make the estimates more reliable, I have arbitrarily restricted my analysis to those tracts with at least 200 occupied housing units in both 2000 and 2010, leaving 58,264 tracts with sufficient observations in both 2000 and 2010.10 This corresponds to an average of 32 Census long-form interviews per tract in 2000, and 22 ACS interviews in 2008-2012.

In addition, tracts were characterized by (1) the Census region (Northeast, Midwest, South, and West), (2) the size of metropolitan area they were in, and (3) the level of metropolitan area median income. The four metropolitan area population classes and the number of census tracts in each are: Small (under 350,000 people) 7,889 tracts, Medium (350,000 to 599,999 people) - 6,052 tracts, Large (600,000 to 1,499,000 people) - 11,710 tracts, and Very Large (1.5 million people or more) - 32,613 tracts. The four metropolitan income classes are determined by quartiles of median household income in 2000 (each roughly 14,600 tracts): Low -- $\$ 24,863$ to $\$ 39,288$, Middle -- $\$ 39,289$ to $\$ 44,223$, High -- $\$ 44,224$ to $\$ 49,175$, and Very High -- $\$ 49,176$ to $\$ 74,335$.

Based on the work of Duncan and Aber (1997), I hypothesize that one additional categorization would be useful: diversity (heterogeneity), with higher levels of socioeconomic diversity likely to be associated with higher levels of income inequality as well. Since no generally recognized approach is available, I created one by categorizing

\footnotetext{
${ }^{10}$ Because the ACS imposes additional sample size restrictions on published tabulations, analyses of 2010 estimates alone and of the change from 2000 to 2010 use fewer tracts $(57,318)$.
} 
tracts according to six characteristics likely to be related to diversity: percentage who were not non-Hispanic White, percentage of households not headed by a married couple, percentage of households which rent, percentage of individuals 25 or older with less than a high school diploma, percentage crowded (more than 1 person per room), and percentage of those 16 or older who were unemployed. Each tract was given a score of 0 to 3 for each of these characteristics, depending on which quartile of its distribution it fell. These scores were then summed; in 2000, 2.53\% of tracts had a diversity index of 0 and 4.39\% has a diversity index of 18 (the maximum); in 2010 the figures were 1.64\% and $2.58 \%$, respectively. For the purpose of presenting results categorized by diversity, the 2000 index was rescaled into rough quintiles: scores 0-3 (18\% of tracts), 4-7 (25\%), 8-10 (17\%), 11-14 (20\%), and 15-18 (20\%).

\section{FINDINGS}

Figure 1 shows the relationship at the metropolitan area level between the level of the Gini index of household income inequality in 2000 and the index in 2010 - the correlation is 0.775 , with a downward trend line versus the 45 -degree line (that is, demonstrating regression to the mean). ${ }^{11,12}$ Figure 2 shows that, at the metropolitan area level, the higher the Gini index in 2000, the smaller the increase in Gini between 2000 and 2010 (the mean change in the Gini index for tracts between 2000 and 2010 is +0.006 with a standard deviation of 0.058).

\subsection{Point-in-Time Regressions}

\footnotetext{
11 The correlation at the tract level is 0.640 .

12 The three metropolitan areas with the lowest 2000 Gini (that is, most equal) and five of the lowest ten are in Wisconsin.
} 
Table 1 presents the basic regression results, with cross-section regressions of the Gini index on tract characteristics for 2000 and 2010, including a quadratic term for the percent in poverty. ${ }^{13}$ The goodness- of-fit $\left(\mathrm{R}^{2}\right)$ of both cross-section equations is quite good (0.606 and 0.519). All the included characteristics have a significant effect on the Gini coefficient in at least one year, and 30 of the 33 characteristics do in both years. The effects of the various characteristics are quite similar across the two years, with only 4 of the 33 characteristics affecting the Gini index in significantly opposite directions in the two regressions, though most of these effects are quite small; these opposite signs are possibly due to multicollinearity.

To determine the characteristics with the most effect on the cross-section Gini index, I calculated the effect of a $10 \%$ (not percentage point) increase in each independent variable, with the other characteristics held at their sample means. There are only four variables with marginal effects of 0.004 Gini points or more in both years: percent below poverty ( 0.007 points in 2000 and 0.006 points in 2010), percent with a bachelor's degree (0.004 and 0.005), percent of married couple households (0.010 and 0.005), and percent of householders living alone (0.007 and 0.004). ${ }^{14}$ Other characteristics with effects of 0.004 or above in one year were percent non-Hispanic White alone (0.008) and percent single-parent householders (0.004), for 2000, and median housing value (0.004) and median household income (-0.004), for 2010.

\footnotetext{
${ }^{13}$ I also tested quadratic terms for income, rent, and home value; these added no additional explanatory power.

${ }^{14}$ Since the quadratic term for percent in poverty is negative, the positive effect of the poverty rate on the Gini decreases as poverty increases, though not steeply.
} 
I then attempted to learn if different classifications of tracts led to a difference in the quantitatively important descriptors of the Gini index. ${ }^{15}$ Table 2 presents the characterization of significant coefficients for the national-level regression, the 3 subcategories examined (region, population size, and median income), and for the 21 largest metropolitan areas independently. ${ }^{16}$ The results are consistent, suggesting it is only eight key demographic characteristics that one should focus on as quantitatively important in affecting the level of neighborhood income inequality: percent nonHispanic White alone, percent with a bachelor's degree, percent married couple families, percent single-parent households, percent living alone, percent in poverty, median home value, and median household income. However, explaining the Gini coefficient in 2000 or in 2010 using only these eight independent variables explains significantly less than does the full complement of 33 variables, for both years.

Another way of examining the key variables is by use of factor analysis. Factor analysis is designed to summarize the contributions of many independent variables in a smaller number of factors, each one a weighted combination of all the variables. There are six factors with eigenvalues greater than 1.0 that together explain $74 \%$ of the

\footnotetext{
${ }^{15}$ Note however that as one divides the sample into smaller groups, the possibility arises that the smaller sample sizes will affect the determination of significance without affecting the magnitude of the estimated effect. This should not be too serious a concern, though, as the smallest selection (the Denver MA in 2010) has 567 tracts.

${ }^{16}$ The regression coefficients are available from the author. The $21 \mathrm{MAs}$ surround the following major cities: Atlanta, Baltimore, Boston, Chicago, Dallas, Denver, Detroit, Houston, Los Angeles, Miami, Minneapolis, New York, Philadelphia, Phoenix, Riverside, St. Louis, San Diego, San Francisco, Seattle, Tampa, and Washington. $R^{2}$ for the 42 regressions ranges from 0.502 and 0.492 for Tampa in 2000 and 2010, respectively, to 0.759 for Baltimore in 2000 and 0.740 for Denver in 2010.
} 
variance in the Gini index at the tract level in 2000. All of the explanatory variables that affect the Gini most strongly, as indicated by their appearance in Table 2, appear in the first six factors, except for percent Black, percent Asian, and percent moving between 1995 and 2000 (see Table 3).

\subsection{Change Regressions}

The transition matrix from the quintile of the tract Gini in 2000 to 2010 is shown in Table 4 . This matrix is notably unstable - only $39.5 \%$ of tracts stay in the same quintile, with the most stability at the ends of the distribution (panel A shows that 53.3\% of tracts in the lowest quintile in 2000 stay there and $55.1 \%$ of tracts in the highest quintile stay there). But the traditional way of looking at transitions by looking at quintiles does not take account of the fact that the indexes are heavily concentrated around the mean. Another and perhaps more informative way of looking at the transitions demonstrates the opposite: stability. Panel B shows that $84.4 \%$ of tracts within one standard deviation of the mean in 2000 stay within one standard deviation of the mean in 2010 . There appears to be more stability at the high end, where $28.1 \%$ of tracts with Gini more than two standard deviations above the mean stay in that category 10 years later, versus only 6.5\% staying in the lowest category (more than two standard deviations below the mean).

Table 5 presents the regression of the change in the Gini between 2000 and 2010 on baseline 2000 characteristics, including the Gini index in 2000, and on changes in characteristics between 2000 and 2010. ${ }^{17}$ In addition to the 2000 Gini index, with a large negative coefficient and strong marginal effect, there were five baseline

\footnotetext{
${ }^{17}$ The combined equation had significantly better fit $\left(\mathrm{R}^{2}=0.474\right)$ than the equation with only baseline characteristics (0.356) or only change characteristics (0.137).
} 
characteristics that were associated with a 0.002 point or more marginal effect on the change in the Gini index associated with a $10 \%$ change in the characteristic - percent non-Hispanic White alone $(+0.003)$, percent with a bachelor's degree $(+0.003)$, percent married couples $(+0.004)$, percent living alone $(+0.003)$, and percent in poverty (+0.003) - but there were no change characteristics with that large an effect (see Figure 3). Other characteristics with a modest marginal effect were median home value (+), rent (-), and income (-), and percent owner-occupied (+), and the change in median value (+) and rent (-).

Another way of looking at the change in the Gini index between 2000 and 2010 is to classify tracts by their relationship to the average change between those two years (an increase of 0.0057). The change was classified into five categories: (1) more than two standard deviations ( 0.058$)$ below the mean change ( $3.1 \%$ of the tracts), (2) more than one but less than or equal to two standard deviations below the mean (10.5\%), (3) within 1 standard deviation of the mean (73.0\%), (4) more than one but less than or equal to two standard deviations above the mean (11.4\%), and (5) more than two standard deviations above the mean (2.0\%). All the tracts in categories 1 and 2 (below the mean) in 2000, and some of the tracts in category 3 (near the mean), had a decline in Gini between 2000 and 2010. When the independent variables from 2000 are examined when the tracts are classified by these five categories of change in the Gini, only three stand out as being different among the categories (that is, being at least one standard deviation below the overall mean for that independent variable), and then only to identify the lowest category of two standard deviations below the mean: percent with less than a high school education (34.1\% in the lowest group versus a mean of 19.5\%), percent unemployed (11.7\% versus $6.2 \%$ ), and percent in poverty (26.0\% versus $12.4 \%$ ). 
Also note that the level of the Gini index in 2000 was 0.543 in the tracts with the largest negative change in Gini, higher than the mean Gini index across all tracts of 0.407.

I also conducted a discriminant analysis to see if there were key independent variables that could classify the tracts into the five categories of change in the Gini index, based on 2000 tract characteristics. When examining standardized canonical weights, the main influence in the first function was the level of the Gini index in 2000 (related to the finding of regression to the mean over the decade). Very few other variables had high weights; for the second through fourth discriminant functions the key variables were race and ethnicity (percent black, percent non-Hispanic White, and percent Hispanic). While it was easy to classify tracts in the middle of the distribution ( $97 \%$ of those in category 3 were classified into category 3 ), the final discriminant functions were not very successful in classifying tracts into their true classifications, with the best success for category 1 (though even there, only $48 \%$ of 1,782 tracts in category 1 were classified into category 1).

Figure 4 presents yet another way I attempted to uncover the key determinants of change in the Gini index between 2000 and 2010. This figure summarizes the results of regressions when the sample was categorized by five levels of the pre-determined diversity index described above, four metropolitan income categories, four metropolitan population categories, and independently for the 21 largest metropolitan areas (MAs), with the independent variables ordered by the number of significant coefficients in the MA regressions. ${ }^{18}$ The regularity of influences suggests that the following are the key

\footnotetext{
${ }^{18}$ All the regressions are available from the author. Appendix Table A.2 summarizes the significance and direction of those effects.
} 
influences on the change in the Gini index, listed in order of most consistent effects to less:

- Gini index in 2000 (a strong negative influence), negative and significant for all categories and MAs;

- Percent below the poverty level in 1999 (positive) and percent below the poverty level squared (negative), and change in poverty (positive);

- Median housing value of owner-occupied units (positive) and change in value (positive);

- Percent of those 25 years or older with a Bachelor's degree (positive) and change in this proportion (positive);

- Median household income (negative) and change in income (negative);

- Percent 65 and older (positive) and change in this proportion (positive);

- Median gross rent (negative) and change in rent (negative);

- Percent of householders living alone (positive) and change in this proportion (positive);

- Density (units per square mile) (negative);

- Percent owner-occupied units (positive);

- Change in density (housing units per square mile); and

- Change in the percent of households that are married couples (positive).

With the addition of but a few new characteristics (percent 65 and older, density), these are much the same characteristics that had influence on the level of the Gini index. The goodness of fit does not vary by population category or income category (all $\mathrm{R}^{2}$ are in the 0.46 to 0.50 range); there are no variables for which the direction in one 
category differs from the direction in the other three for either population or income. In contrast, the goodness of fit varies strongly with the 2000 level of diversity, as measured by my constructed index. As diversity increases, so does the $\mathrm{R}^{2}$. From a low of 0.40 for the lowest level of diversity (scores of 0 to 3 ), the rise in the goodness of fit is monotonic: to $0.42,0.44,0.47$, and finally 0.58 for the highest level of diversity (scores of 15 to 18). Thus, as the level of demographic and economic diversity increases, the better the baseline and change characteristics explain the change in the Gini index from 2000 to 2010.19

Appendix Table A.3 presents the pattern of significance and the sign of the coefficients in the 21 metropolitan area (MA) regressions. There is no particular relationship between the number of tracts and the goodness of fit - the best fit was obtained in Denver (0.658), the MA in this selected group with the smallest number of tracts (567), while the worst fit was in Boston (0.460), with 975 tracts (in the middle of the distribution). Local factors do appear to matter. The goodness of fit for 20 of the 21 MAs exceeded the fit at the national level, that is, the fit for all MAs pooled (0.474). There are however three variables for which a significant coefficient in the regression for one MA differs in direction from those in at least one-third (7) of the other MAs: percent under 18 years old ( 8 with a significant positive coefficient, Miami with a significant negative coefficient), percent 65 years and older (14 positive, Phoenix negative), and percent below poverty squared (Houston positive, 11 negative). All the regressions had

\footnotetext{
19 There is only one variable for which the coefficient for the highest diversity category differs in sign from the other four: the change in the percent 65 years and older.
} 
at least 16 significant coefficients (excluding the constant), while the two largest MAs (New York and Los Angeles) had 38 and 33 significant coefficients, respectively. ${ }^{20}$

\section{CONCLUSIONS AND FUTURE RESEARCH}

Of the 33 tract characteristics examined, only a handful had a substantial effect on the level of the Gini index and on the change in the Gini index from 2000 to 2010 . By far the biggest determinant of the change in the index was the baseline level of the index in 2000: the higher the Gini index, the smaller the change. The key characteristics affecting the change in household income inequality at the neighborhood level between 2000 and 2010 were:

- Percent below the poverty level in 1999 (positive for the baseline characteristic and for the change between 2000 and 2010);

- Median housing value of owner-occupied units (positive for both);

- Percent of those 25 years or more with a bachelor's degree (positive for both);

- Median household income (negative for both);

- Percent 65 years and older (positive for both);

- Median gross rent (includes utilities) (negative for both); and

- Percent of householders living alone (positive for both).

Among these, the most important is the percent in poverty in 1999, though the effect decreases as the percent poor increases. Note also that as the level of demographic and economic diversity increases, the better the baseline and change characteristics explain the change in the Gini index from 2000 to 2010.

20 Of the top ten largest MAs in population, all but two (Detroit and Miami) had 25 or more significant coefficients; all of the others had 16 to 24 significant coefficients. 
One possible extension is to create some metropolitan area case studies, where one used additional variables that could affect inequality but are not measured by ACS data. Variables that could affect the attractiveness of a neighborhood to households might include tract-level crime rates, school achievement measures, environmental hazards (pollution) or advantages (parks), or access indicators (such as to retail establishments, restaurants, health care facilities, or jobs). Another possible extension is to relate the findings to residential segregation. 


\section{REFERENCES}

Bishaw, Alemayehu and J essica Semega. 2008. "Income, Earnings, and Poverty Data from the 2007 American Community Survey." U.S. Census Bureau American Community Survey Report ACS-09, August.

Bond, Eric W. and N. Edward Coulson. 1989. "Externalities, Filtering, and Neighborhood Change.”J ournal of Urban Economics 26: 231-249.

Brueckner, J an. 1977. "The Determinants of Residential Succession." J ournal of Urban Economics 4: 45-59.

Chetty, Raj and Nathaniel Hendren. 2015. "The Impacts of Neighborhoods on Intergenerational Mobility: Childhood Exposure Effects and County-Level Estimates." At < http://scholar.harvard.edu/files/hendren/files/nbhds paper.pdf $>$.

Duncan, Greg J . and J . Lawrence Aber. 1997. "Neighborhood Models and Measures.” Chapter 3 in J eanne Brooks-Gunn, GregJ . Duncan, and J . Lawrence Aber (eds.), Neighborhood Poverty. Volume 1: Context and Consequences for Children. New York: Russell Sage Foundation: 62-78.

Ellen, Ingrid Gould and Katherine O’Regan. 2008. "Reversal of Fortunes? LowerIncome Urban Neighbourhoods in the US in the 1990s." Urban Studies 45(4) 845- 869.

Freedman, Matthew and Tamara MoGavock. 2015. "Low-Income Housing Development, Poverty Concentration, and Neighborhood Inequality." J ournal of the Policy Analysis and Management 34(4): 805-834.

Galster, George and J ason Booza. 2007. "The Rise of the Bipolar Neighborhood." J ournal of the American Planning Association 73(4): 421-435.

Galster, George C., Roberto G. Quercia, Alvaro Cortes, and Ron Malega. 2003. "The Fortunes of Poor Neighborhoods." Urban Affairs Review 39(2): 205-227.

Grigsby, William, Morton Baratz, George Galster, and Duncan Maclennan. 1987. "The Dynamics of Neighborhood Change and Decline." Progress in Planning 28, Part 1: 1-76.

Hardman, Anna and Yannis M. Ioannides. 2004. "Neighbors' Income Distribution: Economic Segregation and Mixing in US Urban Neighborhoods." J ournal of Housing Economics 13: 368- 82.

Hipp, J ohn R. 2007. "Income Inequality, Race, and Place: Does the Distribution of Race and Class Within Neighborhoods Affect Crime Rates?” Criminology 45(3): 665-697.

Iceland, J ohn and Daniel H. Weinberg, with Erica Steinmetz. 2002. Racial and Ethnic Residential Segregation in the United States: 1980-2000. U.S. Census Bureau Census 2000 Special Report CENSR-3. 
Logan, J ohn R., Zengwang Xu, and Brian J . Stults. 2012. “Interpolating US Decennial Census Tract Data from as Early as 1970 to 2010: A Longitudinal Tract Database." Professional Geographer 66(3): 412-420.

Megbolugbe, Isaac F., Marja C. Hoek-Smit and Peter D. Linneman. 1996. "Understanding Neighbourhood Dynamics: A Review of the Contributions of William G. Grigsby.” Urban Studies 33(10): 1779-1795.

Nkansah-Amankra, Stephen, Ashish Dhawain, James Robert Hussey, and Kathryn J . Luchok. 2010. "Maternal Social Support and Neighborhood Income Inequality as Predictors of Low Birth Weight and Preterm Birth Outcome Disparities: Analysis of South Carolina Pregnancy Risk Assessment and Monitoring System Survey, 20002003." Maternal and Child Health J ournal 14: 774-785.

OECD [Organization for Economic Cooperation and Development]. 2014. Society at a Glance 2014: OECD Social Indicators. OECD Publishing.

Reardon, Sean R., Lindsay Fox, and J oseph Townsend. 2015. "Neighborhood Income Composition by Household Race and Income, 1990-2009." Annals of the American Academy of Political and Social Science 660 (J uly): 78-97.

Temkin, Kenneth and William Rohe. 1996. "Neighborhood Change and Urban Policy." J ournal of Planning Education and Research 15: 159-170.

Wei, Fang. 2012. "Neighborhood Change in Metropolitan America.” Dissertation submitted to the Faculty of the Virginia Polytechnic Institute and State University. December 10.

Wei, Fang and Paul L. Knox. 2014. "Neighborhood Change in Metropolitan America, 1990 to 2010." Urban Affairs Review 50(4): 459- 489.

Weicher, John C., Frederick J . Eggers, and Fouad Moumen. 2010. The Long-Term Dynamics of Affordable Rental Housing. A report to the J ohn D. and Catherine T. MacArthur Foundation. Hudson Institute (March).

Weicher, J ohn C. and Thomas G. Thibodeau. 1988. "Filtering and Housing Markets: An Empirical Analysis.” J ournal of Urban Economics 23: 21-40.

Weinberg, Daniel H. 2011. “U.S. Neighborhood Income Inequality in the 2005-2009 Period." U.S. Census Bureau American Community Survey Report ACS-16, October. 
Table 1. Regression of Gini Index of Household Income Inequality on Census Tract Characteristics, 2000 and 2010

\begin{tabular}{|c|c|c|c|c|c|c|}
\hline \multirow[b]{2}{*}{ Variable } & \multicolumn{3}{|c|}{2000} & \multicolumn{3}{|c|}{2010} \\
\hline & Coefficient & Sign. & $\begin{array}{r}\text { Marginal } \\
\text { Effect }\end{array}$ & Coefficient & Sign. & $\begin{array}{l}\text { Marginal } \\
\text { Effect }\end{array}$ \\
\hline Household population (00) & -0.000394 & $* * *$ & -0.00153 & -0.000053 & **** & -0.00019 \\
\hline Housing Units $(00)$ & 0.001331 & $* * *$ & 0.00214 & 0.000375 & $* * *$ & 0.00068 \\
\hline Percent Black or African American alone & 0.001170 & $* * *$ & 0.00163 & 0.000338 & $* * *$ & 0.00051 \\
\hline Percent White alone not Hispanic & 0.001216 & $* * *$ & 0.00810 & 0.000268 & *** & 0.00191 \\
\hline Percent Asian alone & 0.000601 & $* * *$ & 0.00024 & -0.000118 & $* * *$ & -0.00006 \\
\hline Percent American Indian or Alaska Native alone & 0.000896 & $* * *$ & 0.00006 & 0.000416 & *** & 0.00003 \\
\hline Percent Native Hawaiian or Pacific Islander alone & 0.001970 & $* * *$ & 0.00003 & 0.000264 & & 0.00000 \\
\hline Percent Hispanic or Latino (of any race) & 0.001011 & $* * *$ & 0.00133 & 0.000095 & $* * *$ & 0.00016 \\
\hline Percent under 18 years old & -0.000895 & $* * *$ & -0.00229 & -0.000320 & *** & -0.00075 \\
\hline Percent 65 years or older & 0.001093 & $* * *$ & 0.00135 & 0.000983 & *** & 0.00130 \\
\hline $\begin{array}{l}\text { Percent of those } 25 \text { years or more without a high } \\
\text { school diploma }\end{array}$ & 0.000957 & $* * *$ & 0.00187 & 0.000597 & *** & 0.00088 \\
\hline $\begin{array}{l}\text { Percent of those } 25 \text { years or more with a bachelor's } \\
\text { degree }\end{array}$ & 0.001750 & $* * *$ & 0.00449 & 0.001705 & $* * *$ & 0.00502 \\
\hline Percent of households that are married couples & 0.001912 & $* * *$ & 0.00982 & 0.001153 & *** & 0.00547 \\
\hline Percent of householders that are single parents & 0.002527 & $* * *$ & 0.00439 & 0.000983 & $* * *$ & 0.00186 \\
\hline Percent of householders living alone & 0.002272 & $* * *$ & 0.00569 & 0.001421 & *** & 0.00390 \\
\hline Percent owner-occupied units & -0.000240 & $* * *$ & -0.00156 & 0.000205 & *** & 0.00130 \\
\hline Percent of units built in the previous 10 years & 0.000049 & $* * *$ & 0.00008 & -0.000070 & *** & -0.00009 \\
\hline Percent mobile homes & 0.000170 & $* * *$ & 0.00009 & 0.000174 & *** & 0.00008 \\
\hline Percent single-family detached units & -0.000005 & & -0.00003 & -0.000140 & *** & -0.00084 \\
\hline Percent single-family attached units & -0.000148 & $* * *$ & -0.00010 & -0.000197 & *** & -0.00013 \\
\hline Percent of structures with 20 units or more & 0.000122 & $* * *$ & 0.00011 & 0.000224 & *** & 0.00020 \\
\hline $\begin{array}{l}\text { Percent of occupied units with } 1.01 \text { or more persons } \\
\text { per room }\end{array}$ & -0.000153 & $* * *$ & -0.00010 & -0.000571 & *** & -0.00022 \\
\hline $\begin{array}{l}\text { Percent of those } 5 \text { years or older who do not speak } \\
\text { English "very well" }\end{array}$ & -0.000239 & $* * *$ & -0.00021 & -0.000148 & *** & -0.00014 \\
\hline Percent of households moving 1995 to 2000 & -0.000606 & $* * *$ & -0.00302 & \multicolumn{3}{|c|}{ NA } \\
\hline Percent of households moving in the past year & \multicolumn{3}{|c|}{ NA } & -0.000188 & *** & -0.00029 \\
\hline $\begin{array}{l}\text { Percent of those } 16 \text { years or older in the civilian } \\
\text { labor force who are unemployed }\end{array}$ & 0.000237 & $* * *$ & 0.00015 & 0.000238 & *** & 0.00024 \\
\hline Percent below the poverty level in 1999 & 0.005550 & $* * *$ & 0.00686 & 0.003776 & *** & 0.00589 \\
\hline Percent foreign born & 0.000122 & $* * *$ & 0.00015 & -0.000232 & *** & -0.00033 \\
\hline Units per square mile $(00)$ & -0.000042 & $* * *$ & -0.00011 & -0.000053 & $* * *$ & -0.00014 \\
\hline Median gross rent (includes utilities) $(\$ 00)$ & -0.002724 & $* * *$ & -0.00188 & -0.002873 & *** & -0.00292 \\
\hline $\begin{array}{l}\text { Median housing value of owner-occupied units } \\
(\$ 0000)\end{array}$ & 0.001731 & $* * *$ & 0.00260 & 0.001636 & *** & 0.00403 \\
\hline Median household income $(\$ 000)$ & -0.000319 & $* * *$ & -0.00152 & -0.000751 & $* * *$ & -0.00446 \\
\hline $\begin{array}{l}\text { Median travel time of workers } 16 \text { years or older not } \\
\text { working at home (minutes) }\end{array}$ & -0.000038 & & -0.00010 & -0.000168 & *** & -0.00043 \\
\hline Percent below the poverty level in 1999 squared & -0.0000003 & $* * *$ & 0.00000 & -0.0000002 & *** & 0.00000 \\
\hline Constant & 0.030756 & $* *$ & & 0.197372 & $* * *$ & \\
\hline Observations & \multicolumn{3}{|c|}{58,264} & \multicolumn{3}{|c|}{57,318} \\
\hline $\mathbf{R}^{\mathbf{2}}$ & \multicolumn{3}{|c|}{0.606} & \multicolumn{3}{|c|}{0.519} \\
\hline
\end{tabular}

SOURCES: 2000: 2000 decennial census retabulated to 2010 census tract boundaries; 2010: 2008-2012

American Community Survey (5-year estimates).

NOTES: Includes only the metropolitan area census tracts with at least 200 occupied housing units in both years.

$\mathrm{NA}=$ not applicable. Sign. $=$ Significance; confidence levels: $* / * * * * *=0.10 / 0.05 / 0.01$. Marginal effect is the effect on the dependent variable of increasing the independent variable by $10 \%$ while holding all other independent variables at their sample mean. 
Table 2. Number and Size of Marginal Effects on the Gini Index Exceeding 0.004, for National and Categorical Cross-Section Regressions, 2000 and 2010

\begin{tabular}{|c|c|c|c|c|c|c|c|c|c|c|}
\hline \multirow[b]{2}{*}{ Characteristic } & \multicolumn{5}{|c|}{2000} & \multicolumn{5}{|c|}{2010} \\
\hline & National & $\begin{array}{r}\text { Of } 4 \\
\text { regions }\end{array}$ & $\begin{array}{r}\text { Of } 4 \\
\text { population } \\
\text { categories }\end{array}$ & $\begin{array}{r}\text { Of } 4 \\
\text { income } \\
\text { categories }\end{array}$ & $\begin{array}{r}\text { Of } 21 \\
\text { metropolitan } \\
\text { areas }\end{array}$ & National & $\begin{array}{r}\text { Of } 4 \\
\text { regions }\end{array}$ & $\begin{array}{r}\text { Of } 4 \\
\text { population } \\
\text { categories }\end{array}$ & $\begin{array}{r}\text { Of } 4 \\
\text { income } \\
\text { categories }\end{array}$ & $\begin{array}{r}\text { Of } 21 \\
\text { metropolitan } \\
\text { areas }\end{array}$ \\
\hline Percent Black or African American alone & NO & $1+$ & 0 & 0 & 4 & NO & 0 & 0 & 0 & 0 \\
\hline Percent White alone not Hispanic & YES,+ & $3+$ & $3+$ & 0 & $16+, 3-$ & NO & 0 & 0 & 0 & $5+, 1-$ \\
\hline Percent Asian alone & NO & $1+$ & 0 & 0 & 0 & NO & 0 & 0 & 0 & 0 \\
\hline Percent Hispanic or Latino (of any race) & NO & $1+$ & 0 & 0 & $8+$ & NO & 0 & 0 & 0 & 0 \\
\hline Percent under 18 years old & NO & 0 & 0 & 0 & $2-$ & NO & 0 & 0 & 0 & 0 \\
\hline $\begin{array}{l}\text { Percent of those } 25 \text { years or more without a high } \\
\text { school diploma }\end{array}$ & NO & 0 & 0 & 0 & $2+$ & NO & 0 & 0 & 0 & 0 \\
\hline $\begin{array}{l}\text { Percent of those } 25 \text { years or more with a bachelor's } \\
\text { degree }\end{array}$ & YES,+ & $3+$ & $4+$ & $4+$ & $13+$ & YES,+ & $3+$ & $4+$ & $4+$ & $13+$ \\
\hline Percent of households that are married couples & YES,+ & $4+$ & $4+$ & $4+$ & $16+, 1-$ & YES,+ & $4+$ & $4+$ & $4+$ & $9+$ \\
\hline Percent of householders that are single parents & YES,+ & $2+$ & $3+$ & $3+$ & $9+$ & NO & 0 & 0 & 0 & $1+$ \\
\hline Percent of householders living alone & YES,+ & $4+$ & $4+$ & $4+$ & $15+, 1-$ & YES,+ & $2+$ & $2+$ & $3+$ & $7+$ \\
\hline Percent owner-occupied units & NO & 0 & 0 & 0 & $4-$ & NO & 0 & 0 & 0 & $3+$ \\
\hline Percent single-family detached units & NO & 0 & 0 & 0 & $2-$ & NO & 0 & 0 & 0 & $2-$ \\
\hline Percent of households moving 1995 to 2000 & NO & 0 & 0 & 0 & $5-$ & NA & & & & \\
\hline Percent below the poverty level in 1999 & YES,+ & $4+$ & $4+$ & $4+$ & $20+$ & YES,+ & $4+$ & $4+$ & $4+$ & $21+$ \\
\hline Median gross rent & NO & 0 & 0 & 0 & 0 & NO & 0 & 0 & 0 & $4-$ \\
\hline Median housing value of owner-occupied units & NO & 0 & $3+$ & $1+$ & $14+$ & YES,+ & $4+$ & $4+$ & $3+$ & $19+$ \\
\hline Median household income & NO & $1-$ & 0 & 0 & 7- & YES,- & $3-$ & 4- & $3-$ & $17-$ \\
\hline
\end{tabular}

SOURCES: See Table 1.

NOTES: Shown in the table are the number of times that the effect of a 10 percent increase in the indicated independent variable, evaluated at the means of all other independent variables, leads to a change in the Gini coefficient of 0.004 or more (signs of effects are indicated). Excludes all variables where no marginal effects of sufficient size were found. NA = Not applicable. 
Table 3. Census Tract Characteristics with the Largest Influence on the Rotated Factor Loadings for the Gini Index of Household Inequality in 2000

\begin{tabular}{|c|c|c|c|c|c|}
\hline Factor 1 & Factor 2 & Factor 3 & Factor 4 & Factor 5 & Factor 6 \\
\hline $\begin{array}{l}\% \text { White alone } \\
\text { not Hispanic [-] }\end{array}$ & $\begin{array}{l}\% \text { under } 18 \\
{[+]}\end{array}$ & $\begin{array}{l}\% \text { with a } \\
\text { bachelor's } \\
\text { degree }[+]\end{array}$ & $\begin{array}{l}\text { \% White } \\
\text { alone not } \\
\text { Hispanic } \\
{[-]}\end{array}$ & $\begin{array}{l}\% \\
\text { unemployed } \\
{[+]}\end{array}$ & $\begin{array}{l}\text { Household } \\
\text { population } \\
{[+]}\end{array}$ \\
\hline$\%$ Hispanic $[+]$ & $\begin{array}{l}\% \text { married } \\
\text { couples }[+]\end{array}$ & $\begin{array}{l}\text { Median } \\
\text { gross rent } \\
{[+]}\end{array}$ & $\begin{array}{l}\% \text { single } \\
\text { parents } \\
{[+]}\end{array}$ & $\begin{array}{l}\text { \% below the } \\
\text { poverty level } \\
{[+]}\end{array}$ & $\begin{array}{l}\text { Housing } \\
\text { units }[+]\end{array}$ \\
\hline $\begin{array}{l}\% \text { without a } \\
\text { high school } \\
\text { diploma }[+]\end{array}$ & $\begin{array}{l}\text { \% living } \\
\text { alone [-] }\end{array}$ & $\begin{array}{l}\text { Median } \\
\text { housing } \\
\text { value }[+]\end{array}$ & & $\begin{array}{l}\% \text { below the } \\
\text { poverty level } \\
\text { squared }[+]\end{array}$ & \\
\hline$\%$ crowded $[+]$ & $\begin{array}{l}\text { \% owner- } \\
\text { occupied [+] }\end{array}$ & $\begin{array}{l}\text { Median } \\
\text { household } \\
\text { income }[+]\end{array}$ & & & \\
\hline $\begin{array}{l}\text { \% who do not } \\
\text { speak English } \\
\text { "very well" [+] }\end{array}$ & $\begin{array}{l}\text { \% single- } \\
\text { family } \\
\text { detached }[+]\end{array}$ & & & & \\
\hline $\begin{array}{l}\% \text { foreign born } \\
{[+]}\end{array}$ & $\begin{array}{l}\% \text { of } \\
\text { structures } \\
\text { with } 20 \text { units } \\
\text { or more [-] }\end{array}$ & & & & \\
\hline
\end{tabular}

SOURCES: See Table 1.

NOTES: Only six factors have eigenvalues of greater than 1.0 in the factor analysis of the influences on the Gini index in 2000. The direction of influence is noted in brackets ([]). 
Table 4. Changes in Tract Gini Index from 2000 to 2010 (Percent of Row Transitions)

\begin{tabular}{|c|c|c|c|c|c|}
\hline \multirow{2}{*}{$\begin{array}{l}\text { Panel A } \\
\text { Quintile in } 2000 \text { (range) } \\
\text { Q rang }\end{array}$} & \multicolumn{5}{|c|}{ Quintile in 2010} \\
\hline & $\begin{array}{c}1 \\
(<0.359) \\
\end{array}$ & $\begin{array}{c}\mathbf{2} \\
(0.359- \\
0.390) \\
\end{array}$ & \multirow[t]{2}{*}{$\begin{array}{c}3 \\
(0.391- \\
0.420) \\
1270 \%\end{array}$} & $\begin{array}{c}\mathbf{4} \\
(0.421- \\
0.461) \\
\end{array}$ & $\begin{array}{c}5 \\
(>0.461) \\
\end{array}$ \\
\hline$(<0.349)$ & $53.3 \%$ & $25.9 \%$ & & $6.1 \%$ & $2.0 \%$ \\
\hline $2(0.349-0.382)$ & $24.6 \%$ & $30.8 \%$ & $24.6 \%$ & $14.5 \%$ & $5.4 \%$ \\
\hline $3(0.383-0.416)$ & $12.5 \%$ & $23.1 \%$ & $27.3 \%$ & $25.2 \%$ & $11.8 \%$ \\
\hline $4(0.417-0.461)$ & $6.4 \%$ & $14.2 \%$ & $22.6 \%$ & $31.0 \%$ & $25.8 \%$ \\
\hline $5 \quad(>0.461)$ & $2.5 \%$ & $6.3 \%$ & $12.1 \%$ & $24.0 \%$ & $55.1 \%$ \\
\hline Panel B & \multicolumn{5}{|c|}{ Distribution in $2010^{\mathrm{b}}$ ( $\%$ of tracts) } \\
\hline $\begin{array}{l}\text { Distribution in } 2000^{a} \\
\text { (\% of tracts) }\end{array}$ & $\begin{array}{c}<2 \text { sd } \\
\text { below } \\
\text { mean } \\
(0.3 \%) \\
\end{array}$ & $\begin{array}{c}\text { 1-2 sd } \\
\text { below } \\
\text { mean } \\
(9.0 \%) \\
\end{array}$ & $\begin{array}{r}\text { within } 1 \\
\text { sd of } \\
\text { mean } \\
(75.9 \%) \\
\end{array}$ & $\begin{array}{r}\text { 1-2 sd } \\
\text { above } \\
\text { mean } \\
(11.5 \%)\end{array}$ & $\begin{array}{l}<2 \text { sd } \\
\text { above } \\
\text { mean } \\
(3.3 \%)\end{array}$ \\
\hline$<2$ sd below mean $(2.7 \%)$ & $6.5 \%$ & $56.1 \%$ & $36.8 \%$ & \multirow{2}{*}{\multicolumn{2}{|c|}{$8.0 \%$}} \\
\hline 1-2 sd below mean ( $17.0 \%)$ & $0.5 \%$ & $25.2 \%$ & $73.1 \%$ & & \\
\hline within 1 sd of mean $(65.0 \%)$ & $0.1 \%$ & $4.8 \%$ & $84.4 \%$ & $9.4 \%$ & $1.3 \%$ \\
\hline $\begin{array}{l}1-2 \text { sd above mean }(10.8 \%) \\
>2 \text { sd above mean }(4.5 \%)\end{array}$ & \multicolumn{2}{|c|}{$1.0 \%$} & $\begin{array}{l}54.3 \% \\
37.9 \%\end{array}$ & $\begin{array}{l}34.2 \% \\
33.7 \%\end{array}$ & $\begin{array}{l}10.7 \% \\
28.1 \%\end{array}$ \\
\hline
\end{tabular}

SOURCES: See Table 1.

NOTES: $s d=$ standard deviation. The Gini index at the tract level is correlated at 0.640 between the level in 2000 and that in 2010 .

a. Gini index in 2000: mean $=0.413$ and standard deviation $=0.064$.

b. Gini index in 2010: mean $=0.407$ and standard deviation $=0.071$. 
Table 5. Regression of 2000 to 2010 Change in Census Tract Gini Index of Household Income Inequality on Baseline (2000) and Tract Change Characteristics

\begin{tabular}{|c|c|c|c|}
\hline Independent Variable & Coefficient & $\begin{array}{l}\text { Signifi- } \\
\text { cance }\end{array}$ & $\begin{array}{l}\text { Marginal } \\
\text { Effect }\end{array}$ \\
\hline Gini index of household income inequality in 2000 & -0.699771 & (*** & -0.0285 \\
\hline Household population (00) & -0.000006 & & 0.0000 \\
\hline Housing Units (00) & 0.000316 & $* * *$ & 0.0005 \\
\hline Percent Black or African American alone & 0.000437 & $* * *$ & 0.0006 \\
\hline Percent White alone not Hispanic & 0.000482 & $* * *$ & 0.0032 \\
\hline Percent Asian alone & 0.000286 & $* *$ & 0.0001 \\
\hline Percent American Indian or Alaska Native alone & 0.000662 & $* * *$ & 0.0000 \\
\hline Percent Native Hawaiian or Pacific I slander alone & 0.000740 & $* *$ & 0.0000 \\
\hline Percent Hispanic or Latino (of any race) & 0.000401 & $* * *$ & 0.0005 \\
\hline Percent under 18 years old & 0.000024 & & 0.0001 \\
\hline Percent 65 years or older & 0.000468 & $* * *$ & 0.0006 \\
\hline $\begin{array}{l}\text { Percent of those } 25 \text { years or more without a high } \\
\text { school diploma }\end{array}$ & 0.000220 & $* * *$ & 0.0004 \\
\hline $\begin{array}{l}\text { Percent of those } 25 \text { years or more with a bachelor's } \\
\text { degree }\end{array}$ & 0.001240 & $* * *$ & 0.0032 \\
\hline Percent of households that are married couples & 0.000774 & $* * *$ & 0.0040 \\
\hline Percent of householders that are single parents & 0.000625 & $* * *$ & 0.0011 \\
\hline Percent of householders living alone & 0.001098 & $* * *$ & 0.0027 \\
\hline Percent owner-occupied units & 0.000244 & $* * *$ & 0.0016 \\
\hline Percent of units built in the previous 10 years & -0.000009 & & 0.0000 \\
\hline Percent mobile homes & 0.000095 & $* * *$ & 0.0001 \\
\hline Percent single-family detached units & -0.000148 & $* * *$ & -0.0009 \\
\hline Percent single-family attached units & -0.000151 & $* * *$ & -0.0001 \\
\hline Percent of structures with 20 units or more & 0.000139 & $* * *$ & 0.0001 \\
\hline $\begin{array}{l}\text { Percent of occupied units with } 1.01 \text { or more persons } \\
\text { per room }\end{array}$ & -0.000575 & $* * *$ & -0.0004 \\
\hline $\begin{array}{l}\text { Percent of those } 5 \text { years or older who do not speak } \\
\text { English "very well" }\end{array}$ & -0.000125 & * & -0.0001 \\
\hline Percent of households moving 1995 to 2000 & -0.000012 & & -0.0001 \\
\hline $\begin{array}{l}\text { Percent of those } 16 \text { years or older in the civilian } \\
\text { labor force who are unemployed }\end{array}$ & 0.000097 & & 0.0001 \\
\hline Percent below the poverty level in 1999 & 0.002732 & $* * *$ & 0.0034 \\
\hline Percent foreign born & -0.000145 & $* * *$ & -0.0002 \\
\hline Units per square mile $(00)$ & -0.000045 & $* * *$ & -0.0001 \\
\hline Median gross rent (includes utilities) $(\$ 00)$ & -0.002598 & $* * *$ & -0.0018 \\
\hline $\begin{array}{l}\text { Median housing value of owner-occupied units } \\
(\$ 0000)\end{array}$ & 0.001259 & $* * *$ & 0.0019 \\
\hline Median household income $(\$ 000)$ & -0.000307 & $* * *$ & -0.0015 \\
\hline $\begin{array}{l}\text { Median travel time of workers } 16 \text { years or older not } \\
\text { working at home (minutes) }\end{array}$ & -0.000009 & & 0.0000 \\
\hline Percent below the poverty level in 1999 squared & 0.000000 & $* * *$ & -0.0005 \\
\hline \multicolumn{4}{|l|}{ Change from 2000 to 2010 in: } \\
\hline Household population (00) & -0.000030 & $* * *$ & 0.0000 \\
\hline Housing Units (00) & 0.000300 & $* * *$ & 0.0001 \\
\hline Percent Black or African American alone & 0.000128 & $* * *$ & 0.0000 \\
\hline Percent White alone not Hispanic & 0.000190 & $* * *$ & 0.0001 \\
\hline Percent Asian alone & 0.000004 & & 0.0000 \\
\hline
\end{tabular}




\begin{tabular}{|c|c|c|c|}
\hline Percent American Indian or Alaska Native alone & 0.000364 & $* *$ & 0.0000 \\
\hline Percent Native Hawaiian or Pacific Islander alone & 0.000551 & $* *$ & 0.0000 \\
\hline Percent Hispanic or Latino (of any race) & 0.000030 & & 0.0000 \\
\hline Percent under 18 years old & -0.000365 & $* * *$ & 0.0001 \\
\hline Percent 65 years or older & 0.000543 & $* * *$ & 0.0000 \\
\hline $\begin{array}{l}\text { Percent of those } 25 \text { years or more without a high } \\
\text { school diploma }\end{array}$ & 0.000016 & & 0.0000 \\
\hline $\begin{array}{l}\text { Percent of those } 25 \text { years or more with a } \\
\text { bachelor's degree }\end{array}$ & 0.001132 & $* * *$ & 0.0004 \\
\hline Percent of households that are married couples & 0.000712 & $* * *$ & -0.0003 \\
\hline Percent of householders that are single parents & 0.000523 & $* * *$ & 0.0001 \\
\hline Percent of householders living alone & 0.001021 & $* * *$ & 0.0002 \\
\hline Percent owner-occupied units & 0.000187 & $* * *$ & 0.0000 \\
\hline Percent of units built in the previous 10 years & 0.000150 & $* * *$ & -0.0001 \\
\hline Percent mobile homes & 0.000055 & & 0.0000 \\
\hline Percent single-family detached units & -0.000028 & & 0.0000 \\
\hline Percent single-family attached units & -0.000170 & $* * *$ & 0.0000 \\
\hline Percent of structures with 20 units or more & 0.000189 & $* * *$ & 0.0000 \\
\hline $\begin{array}{l}\text { Percent of occupied units with } 1.01 \text { or more } \\
\text { persons per room }\end{array}$ & -0.000410 & $* * *$ & 0.0001 \\
\hline $\begin{array}{l}\text { Percent of those } 5 \text { years or older who do not } \\
\text { speak English "very well" }\end{array}$ & -0.000135 & $* *$ & 0.0000 \\
\hline $\begin{array}{l}\text { Percent of those } 16 \text { years or older in the civilian } \\
\text { labor force who are unemployed }\end{array}$ & -0.000001 & & 0.0000 \\
\hline Percent below the poverty level in 1999 & 0.001972 & $* * *$ & 0.0006 \\
\hline Percent foreign born & 0.000018 & & 0.0000 \\
\hline Units per square mile $(00)$ & 0.000083 & $* * *$ & 0.0000 \\
\hline Median gross rent (includes utilities) $(\$ 00)$ & -0.001538 & $* * *$ & -0.0005 \\
\hline $\begin{array}{l}\text { Median housing value of owner-occupied units } \\
(\$ 0000)\end{array}$ & 0.001111 & $* * *$ & 0.0011 \\
\hline Median household income $(\$ 000)$ & -0.001163 & $* * *$ & -0.0013 \\
\hline $\begin{array}{l}\text { Median travel time of workers } 16 \text { years or older } \\
\text { not working at home (minutes) }\end{array}$ & -0.000092 & $*$ & 0.0000 \\
\hline Constant & 0.099181 & $* * *$ & NA \\
\hline Observations & \multicolumn{3}{|c|}{57,318} \\
\hline $\mathbf{R}^{2}$ & \multicolumn{3}{|c|}{0.474} \\
\hline
\end{tabular}

SOURCES and NOTES: See Table 1. 
Figure 1. Relationship of Metropolitan Area Household Income Gini Indexes: 2000 and 2010

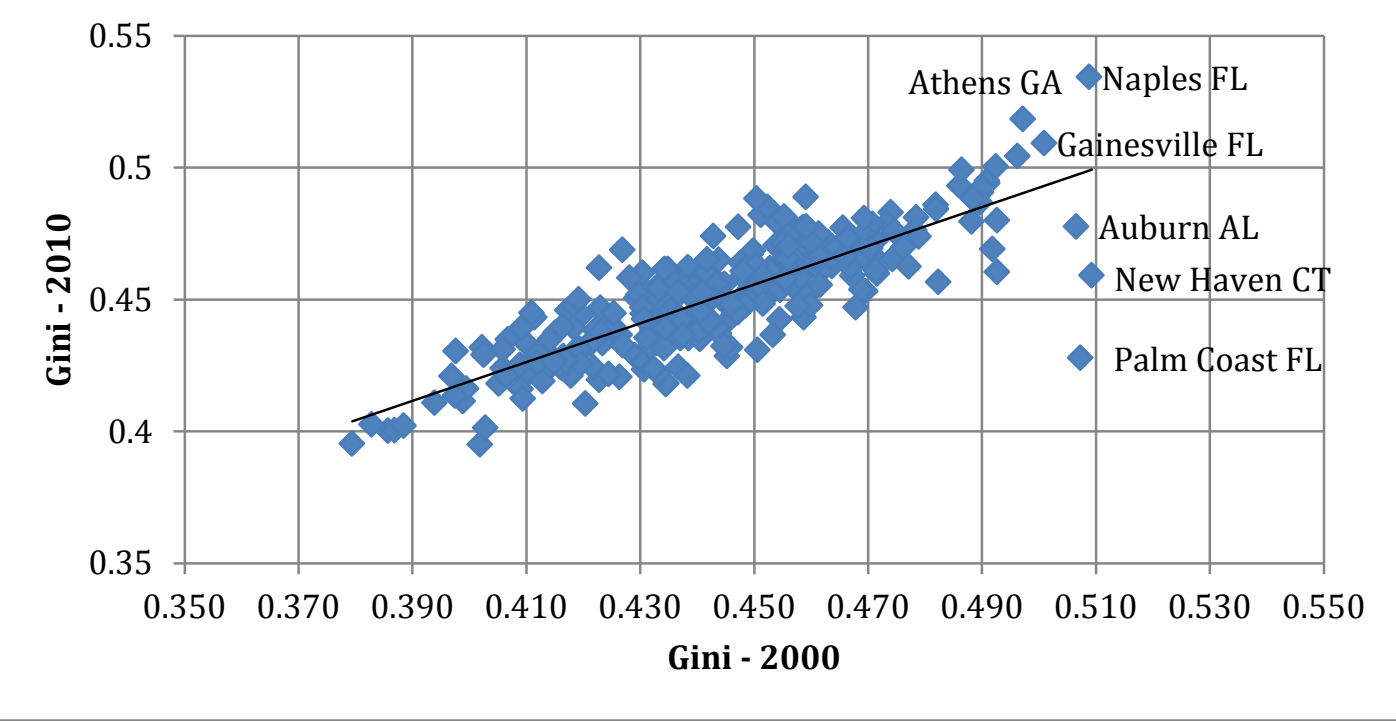

SOURCE: Author's calculations from 2000 Census and 2010 American Community Survey published tables.

NOTES: Excludes metropolitan areas which were not defined in 2000 or whose boundaries were significantly redefined in 2010 .

Figure 2. Relationship of 2000 to 2010 Change in Metropolitan Area Household Income Gini Index to Gini Index Value in 2000

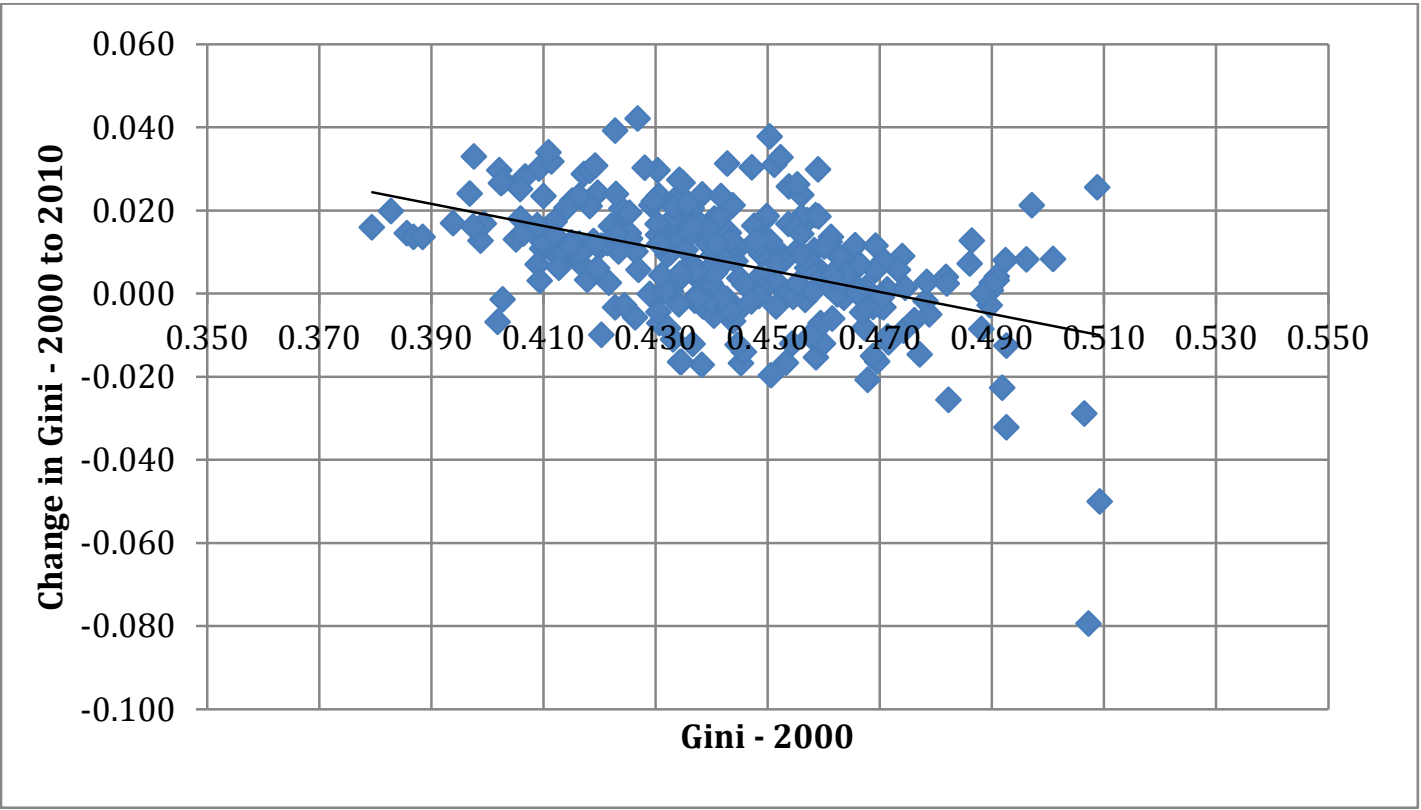

SOURCE: Author's calculations from 2000 Census and 2010 American Community Survey published tables.

NOTES: Excludes metropolitan areas which were not defined in 2000 or whose boundaries were significantly redefined in 2010. 
Figure 3. Marginal Effects of Tract Baseline (2000) and Change Characteristics on the 2000 to 2010 Change in Census Tract Gini Index, All Metropolitan Areas pooled

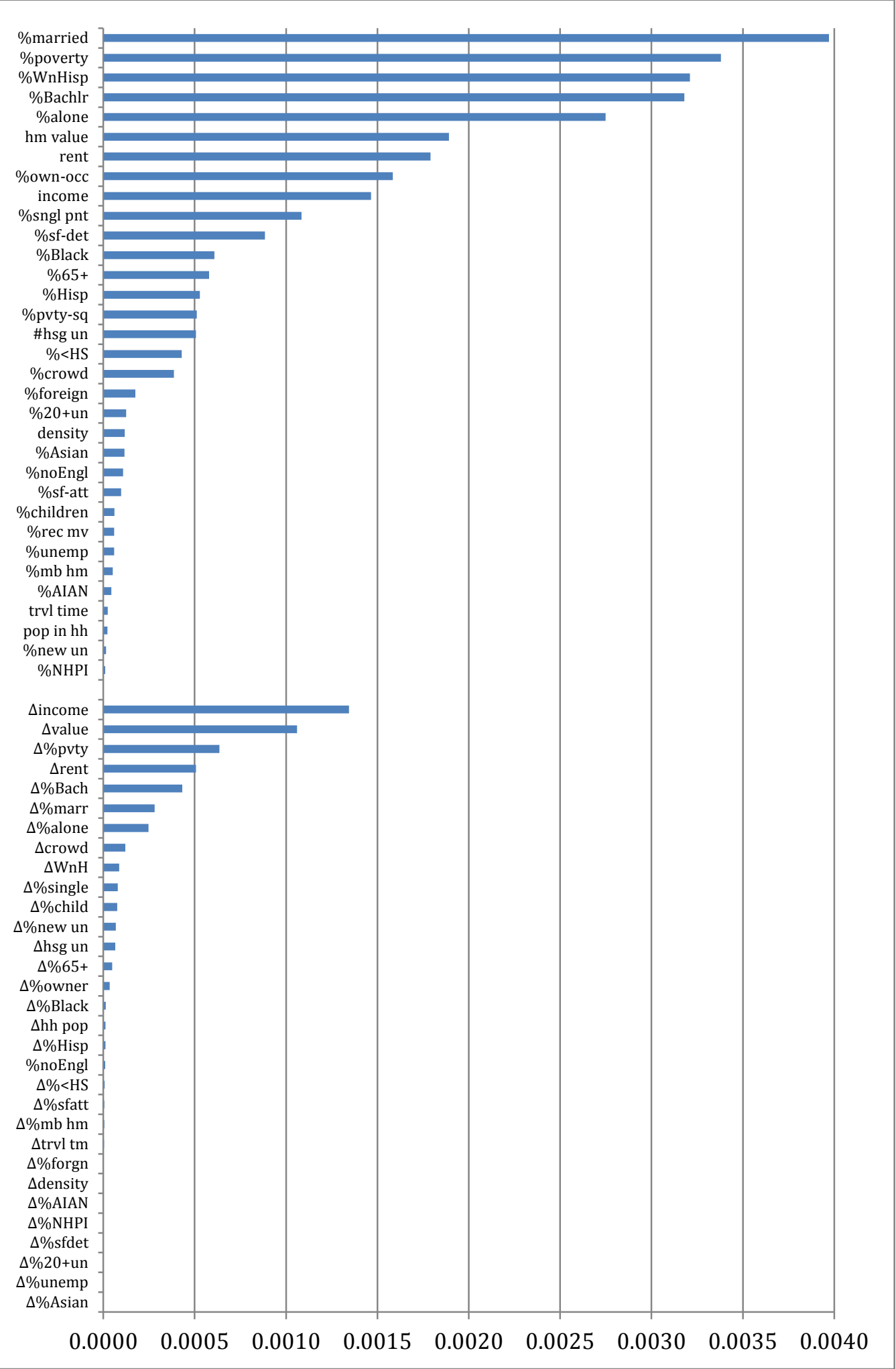

SOURCES and NOTES: See Table 1. Marginal effect of Gini index in 2000 (0.0285) excluded from the figure. Variable names are explained in full in Table $5 ; \Delta=$ Change. 
Figure 4. Significance of Tract Baseline (2000) and Change Characteristics on 2000 to 2010 Change in Census Tract Gini Index, by Categories of Tracts

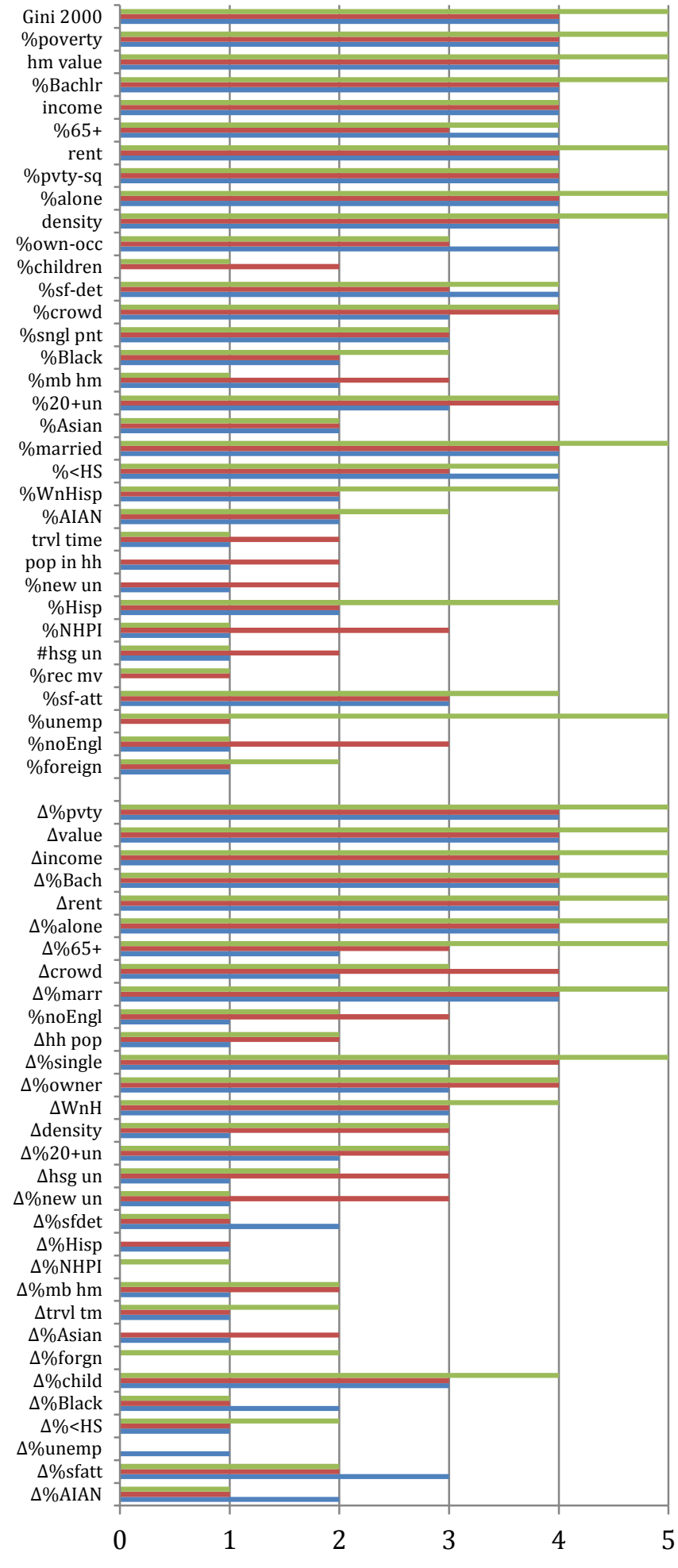

$\square$ Diversity $\square$ Income $\square$ Population $\quad<==$ Categories

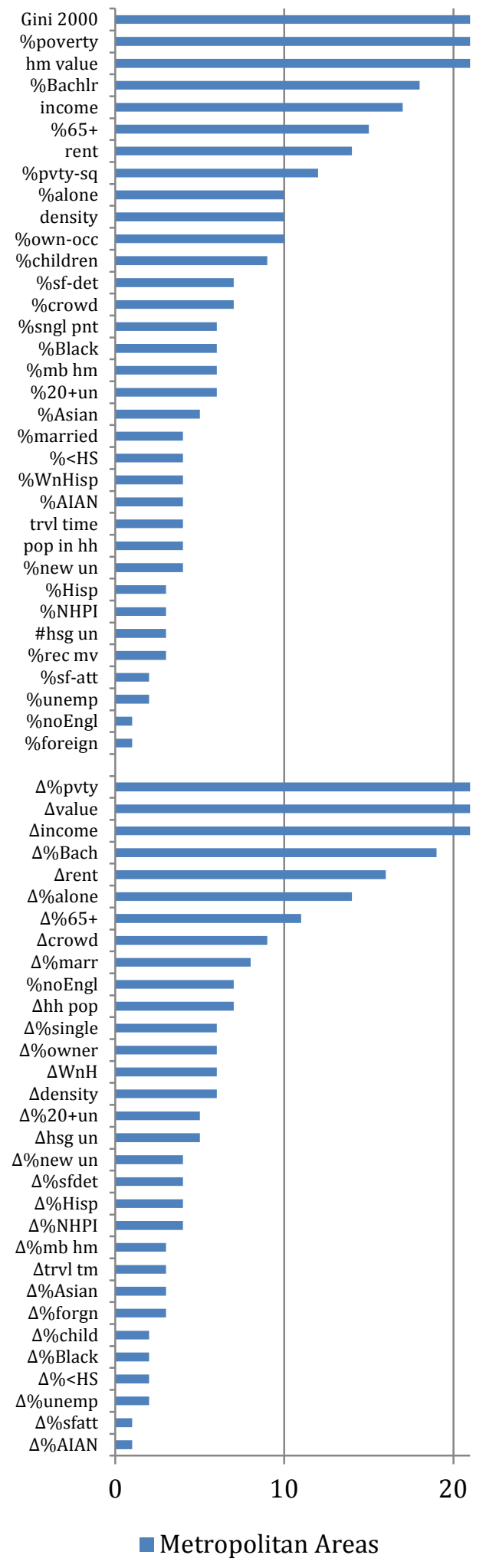

SOURCES and NOTES: See Table 1. Variable names are explained in full in Table 5; $\Delta$ = Change. 
APPENDIX TABLE A.1. Description of Tract-level Variables Used in the Analysis

\begin{tabular}{|c|c|c|c|c|}
\hline Variable & Percentile & 2000 & 2008-2012 & Change \\
\hline \multirow{4}{*}{$\begin{array}{l}\text { Gini index of } \\
\text { household income }\end{array}$} & 25 & 0.359 & 0.368 & -0.027 \\
\hline & 50 & 0.399 & 0.406 & 0.008 \\
\hline & 75 & 0.449 & 0.450 & 0.041 \\
\hline & mean & 0.407 & 0.413 & 0.006 \\
\hline \multirow{4}{*}{$\begin{array}{l}\text { Household } \\
\text { population (00) }\end{array}$} & 25 & 27.47 & 24.35 & -6.01 \\
\hline & 50 & 37.63 & 36.32 & -1.07 \\
\hline & 75 & 49.02 & 49.91 & 3.50 \\
\hline & mean & 38.88 & 34.87 & -4.01 \\
\hline \multirow[t]{4}{*}{ Housing Units (00) } & 25 & 11.34 & 12.62 & 0.05 \\
\hline & 50 & 15.37 & 17.10 & 0.81 \\
\hline & 75 & 20.13 & 22.66 & 2.69 \\
\hline & mean & 16.06 & 18.25 & 2.18 \\
\hline \multirow{4}{*}{$\begin{array}{l}\text { Percent Black or } \\
\text { African American } \\
\text { alone }\end{array}$} & 25 & 1.00 & 1.10 & -0.90 \\
\hline & 50 & 3.50 & 4.70 & 0.20 \\
\hline & 75 & 13.50 & 16.40 & 2.70 \\
\hline & mean & 13.94 & 14.96 & 1.02 \\
\hline \multirow{4}{*}{$\begin{array}{l}\text { Percent White } \\
\text { alone not Hispanic }\end{array}$} & 25 & 47.30 & 58.90 & -3.40 \\
\hline & 50 & 78.70 & 79.90 & 0.70 \\
\hline & 75 & 91.60 & 91.30 & 7.10 \\
\hline & mean & 66.61 & 71.18 & 4.57 \\
\hline \multirow[t]{4}{*}{ Percent Asian alone } & 25 & 0.50 & 0.30 & -0.50 \\
\hline & 50 & 1.50 & 1.90 & 0.20 \\
\hline & 75 & 4.00 & 5.80 & 1.90 \\
\hline & mean & 4.03 & 5.19 & 1.16 \\
\hline \multirow{4}{*}{$\begin{array}{l}\text { Percent American } \\
\text { Indian or Alaska } \\
\text { Native alone }\end{array}$} & 25 & 0.20 & 0.00 & -0.40 \\
\hline & 50 & 0.30 & 0.00 & -0.10 \\
\hline & 75 & 0.70 & 0.60 & 0.10 \\
\hline & mean & 0.68 & 0.63 & -0.05 \\
\hline \multirow{4}{*}{$\begin{array}{l}\text { Percent Native } \\
\text { Hawaiian or Pacific } \\
\text { I slander alone }\end{array}$} & 25 & 0.00 & 0.00 & -0.10 \\
\hline & 50 & 0.00 & 0.00 & 0.00 \\
\hline & 75 & 0.10 & 0.00 & 0.00 \\
\hline & mean & 0.14 & 0.16 & 0.02 \\
\hline \multirow[t]{4}{*}{$\begin{array}{l}\text { Percent Hispanic or } \\
\text { Latino (of any race) }\end{array}$} & 25 & 1.60 & 2.60 & 0.00 \\
\hline & 50 & 4.30 & 7.50 & 2.10 \\
\hline & 75 & 14.30 & 21.60 & 6.30 \\
\hline & mean & 13.19 & 16.99 & 3.81 \\
\hline \multirow{4}{*}{$\begin{array}{l}\text { Percent under } 18 \\
\text { years old }\end{array}$} & 25 & 21.90 & 19.50 & -4.60 \\
\hline & 50 & 25.90 & 23.60 & -2.10 \\
\hline & 75 & 29.80 & 27.70 & 0.40 \\
\hline & mean & 25.54 & 23.44 & -2.10 \\
\hline \multirow[t]{3}{*}{$\begin{array}{l}\text { Percent } 65 \text { years or } \\
\text { older }\end{array}$} & 25 & 7.50 & 8.50 & -1.20 \\
\hline & 50 & 11.10 & 12.30 & 0.90 \\
\hline & 75 & 15.40 & 16.30 & 3.10 \\
\hline
\end{tabular}




\begin{tabular}{|c|c|c|c|c|}
\hline & mean & 12.35 & 13.25 & 0.89 \\
\hline \multirow{4}{*}{$\begin{array}{l}\text { Percent of those } 25 \\
\text { years or more } \\
\text { without a high } \\
\text { school diploma }\end{array}$} & 25 & 8.70 & 5.90 & -8.10 \\
\hline & 50 & 15.90 & 11.20 & -4.00 \\
\hline & 75 & 26.80 & 20.10 & -0.90 \\
\hline & mean & 19.53 & 14.72 & -4.81 \\
\hline \multirow{4}{*}{$\begin{array}{l}\text { Percent of those } 25 \\
\text { years or more with } \\
\text { a bachelor's degree }\end{array}$} & 25 & 11.70 & 14.50 & -0.20 \\
\hline & 50 & 20.90 & 25.00 & 3.30 \\
\hline & 75 & 35.90 & 41.10 & 7.30 \\
\hline & mean & 25.65 & 29.47 & 3.81 \\
\hline \multirow{4}{*}{$\begin{array}{l}\text { Percent of } \\
\text { households that are } \\
\text { married couples }\end{array}$} & 25 & 39.40 & 35.10 & -8.00 \\
\hline & 50 & 52.90 & 48.40 & -3.90 \\
\hline & 75 & 64.00 & 60.20 & 0.20 \\
\hline & mean & 51.34 & 47.40 & -3.94 \\
\hline \multirow{4}{*}{$\begin{array}{l}\text { Percent of } \\
\text { householders that } \\
\text { are single parents }\end{array}$} & 25 & 10.70 & 11.10 & -1.80 \\
\hline & 50 & 14.80 & 16.40 & 1.30 \\
\hline & 75 & 21.30 & 24.50 & 4.70 \\
\hline & mean & 17.36 & 18.87 & 1.52 \\
\hline \multirow{4}{*}{$\begin{array}{l}\text { Percent of } \\
\text { householders living } \\
\text { alone }\end{array}$} & 25 & 17.00 & 18.80 & -1.20 \\
\hline & 50 & 23.40 & 26.00 & 2.20 \\
\hline & 75 & 31.20 & 34.50 & 5.90 \\
\hline & mean & 25.03 & 27.45 & 2.42 \\
\hline \multirow{4}{*}{$\begin{array}{l}\text { Percent owner- } \\
\text { occupied units }\end{array}$} & 25 & 49.20 & 47.30 & -5.60 \\
\hline & 50 & 70.60 & 67.90 & -1.40 \\
\hline & 75 & 84.80 & 82.60 & 2.30 \\
\hline & mean & 64.98 & 63.15 & -1.83 \\
\hline \multirow{4}{*}{$\begin{array}{l}\text { Percent of units } \\
\text { built in the } \\
\text { previous } 10 \text { years }\end{array}$} & 25 & 2.90 & 2.90 & -6.40 \\
\hline & 50 & 9.80 & 8.70 & -1.60 \\
\hline & 75 & 24.70 & 18.60 & 0.70 \\
\hline & mean & 17.22 & 12.66 & -4.56 \\
\hline \multirow[t]{4}{*}{$\begin{array}{l}\text { Percent mobile } \\
\text { homes }\end{array}$} & 25 & 0.00 & 0.00 & -0.80 \\
\hline & 50 & 0.30 & 0.00 & 0.00 \\
\hline & 75 & 4.60 & 3.50 & 0.00 \\
\hline & mean & 5.48 & 4.51 & -0.97 \\
\hline \multirow{4}{*}{$\begin{array}{l}\text { Percent single- } \\
\text { family detached } \\
\text { units }\end{array}$} & 25 & 40.40 & 41.20 & -2.90 \\
\hline & 50 & 65.50 & 66.00 & 0.40 \\
\hline & 75 & 82.40 & 82.70 & 3.90 \\
\hline & mean & 59.62 & 60.03 & 0.41 \\
\hline \multirow{4}{*}{$\begin{array}{l}\text { Percent single- } \\
\text { family attached } \\
\text { units }\end{array}$} & 25 & 0.90 & 0.90 & -1.30 \\
\hline & 50 & 2.70 & 3.10 & 0.00 \\
\hline & 75 & 7.10 & 7.90 & 1.80 \\
\hline & mean & 6.45 & 6.76 & 0.32 \\
\hline \multirow{4}{*}{$\begin{array}{l}\text { Percent of } \\
\text { structures with } 20 \\
\text { units or more }\end{array}$} & 25 & 0.00 & 0.00 & -1.30 \\
\hline & 50 & 2.20 & 2.60 & 0.00 \\
\hline & 75 & 10.60 & 10.40 & 1.10 \\
\hline & mean & 9.03 & 8.98 & -0.05 \\
\hline
\end{tabular}




\begin{tabular}{|c|c|c|c|c|}
\hline \multirow{4}{*}{$\begin{array}{l}\text { Percent of occupied } \\
\text { units with } 1.01 \text { or } \\
\text { more persons per } \\
\text { room }\end{array}$} & 25 & 1.30 & 0.40 & -4.00 \\
\hline & 50 & 3.10 & 1.70 & -1.30 \\
\hline & 75 & 7.70 & 4.50 & 0.00 \\
\hline & mean & 6.72 & 3.80 & -2.92 \\
\hline \multirow{4}{*}{$\begin{array}{l}\text { Percent of those } 5 \\
\text { years or older who } \\
\text { do not speak } \\
\text { English "very well" }\end{array}$} & 25 & 1.60 & 1.50 & -1.20 \\
\hline & 50 & 3.60 & 4.40 & 0.20 \\
\hline & 75 & 10.10 & 12.40 & 2.50 \\
\hline & mean & 8.74 & 9.45 & 0.71 \\
\hline \multirow{4}{*}{$\begin{array}{l}\text { Percent of } \\
\text { households moving } \\
1995 \text { to } 2000 / \text { in } \\
\text { the past } 12 \text { months }\end{array}$} & 25 & 39.10 & 8.80 & NA \\
\hline & 50 & 48.00 & 13.40 & NA \\
\hline & 75 & 58.50 & 19.90 & $\mathrm{NA}$ \\
\hline & mean & 49.84 & 15.51 & NA \\
\hline \multirow{4}{*}{$\begin{array}{l}\text { Percent of those } 16 \\
\text { years or older in } \\
\text { the civilian labor } \\
\text { force who are } \\
\text { unemployed }\end{array}$} & 25 & 2.90 & 5.90 & 1.00 \\
\hline & 50 & 4.60 & 8.60 & 3.60 \\
\hline & 75 & 7.60 & 12.70 & 6.60 \\
\hline & mean & 6.16 & 10.02 & 3.86 \\
\hline \multirow{4}{*}{$\begin{array}{l}\text { Percent below the } \\
\text { poverty level in } \\
\text { 1999/the past } 12 \\
\text { months }\end{array}$} & 25 & 4.40 & 6.00 & -0.70 \\
\hline & 50 & 8.50 & 11.70 & 2.40 \\
\hline & 75 & 16.70 & 21.60 & 6.60 \\
\hline & mean & 12.37 & 15.59 & 3.22 \\
\hline \multirow[t]{4}{*}{$\begin{array}{l}\text { Percent foreign } \\
\text { born }\end{array}$} & 25 & 2.60 & 3.50 & -0.70 \\
\hline & 50 & 6.50 & 8.90 & 1.20 \\
\hline & 75 & 16.20 & 20.20 & 4.30 \\
\hline & mean & 12.12 & 14.05 & 1.93 \\
\hline \multirow[t]{4}{*}{$\begin{array}{l}\text { Units per square } \\
\text { mile }(00)\end{array}$} & 25 & 3.09 & 3.83 & -0.57 \\
\hline & 50 & 11.92 & 12.45 & 0.09 \\
\hline & 75 & 25.17 & 25.07 & 1.20 \\
\hline & mean & 25.86 & 26.27 & 0.41 \\
\hline \multirow{4}{*}{$\begin{array}{l}\text { Median gross rent } \\
\text { (includes utilities) } \\
(\$ 00)^{a}\end{array}$} & 25 & 5.05 & 7.43 & 1.84 \\
\hline & 50 & 6.28 & 9.32 & 2.87 \\
\hline & 75 & 8.01 & 12.07 & 4.34 \\
\hline & mean & 6.89 & 10.18 & 3.30 \\
\hline \multirow{4}{*}{$\begin{array}{l}\text { Median housing } \\
\text { value of owner- } \\
\text { occupied units } \\
(\$ 0000)^{a}\end{array}$} & 25 & 8.40 & 12.15 & 2.91 \\
\hline & 50 & 12.23 & 18.85 & 6.33 \\
\hline & 75 & 17.76 & 31.48 & 13.43 \\
\hline & mean & 15.02 & 24.63 & 9.54 \\
\hline \multirow{4}{*}{$\begin{array}{l}\text { Median household } \\
\text { income in } 1999 / \text { the } \\
\text { past } 12 \text { months } \\
(\$ 000)^{a}\end{array}$} & 25 & 32.73 & 38.97 & 3.44 \\
\hline & 50 & 43.55 & 53.65 & 9.60 \\
\hline & 75 & 58.17 & 73.39 & 17.36 \\
\hline & mean & 47.75 & 59.32 & 11.57 \\
\hline \multirow{4}{*}{$\begin{array}{l}\text { Median travel time } \\
\text { of workers } 16 \text { years } \\
\text { or older not } \\
\text { working at home } \\
\text { (minutes) }\end{array}$} & 25 & 21.40 & 21.00 & -2.60 \\
\hline & 50 & 25.40 & 25.00 & -0.40 \\
\hline & 75 & 30.20 & 29.60 & 1.80 \\
\hline & mean & 26.28 & 25.79 & -0.49 \\
\hline
\end{tabular}

SOURCE: Census 2000 and 2008-2012 American Community Survey. 
NOTES: Observations (number of tracts) $=58,264$ except for the following variables for 2010: value $(57,787)$, rent $(57,806)$, travel time $(58,251)$. NA = not applicable (definition differs between 2000 Census and ACS).

a. The 2008-2012 figures are in 2012 dollars. 
APPENDIX TABLE A.2. Significance and Direction of Effects of Tract Baseline (2000) and Change Characteristics on 2000 to 2010 Change in Census Tract Gini Index, by Categories of Tracts

\begin{tabular}{|c|c|c|c|c|c|c|}
\hline I ndependent Variable & National & $\begin{array}{l}\text { Of } 4 \\
\text { regions }\end{array}$ & $\begin{array}{l}\text { Of } 4 \\
\text { population } \\
\text { categories }\end{array}$ & $\begin{array}{l}\text { Of } 4 \\
\text { income } \\
\text { categories }\end{array}$ & $\begin{array}{l}\text { Of } 5 \\
\text { diversity } \\
\text { categories }\end{array}$ & $\begin{array}{l}\text { Of } 21 \\
\text { metro- } \\
\text { politan } \\
\text { areas } \\
\end{array}$ \\
\hline $\begin{array}{l}\text { Gini index of household } \\
\text { income inequality in } 2000\end{array}$ & YES,- & 4- & 4- & 4- & $5-$ & 21- \\
\hline Household population (00) & NO & 0 & $1+$ & $1+, 1-$ & 0 & $2+, 2$ \\
\hline Housing Units $(00)$ & YES, + & $2+$ & $1+$ & $2+$ & $1+$ & $1+, 2$ \\
\hline $\begin{array}{l}\text { Percent Black or African } \\
\text { American alone }\end{array}$ & YES, + & $2+$ & $2+$ & $2+$ & $3+$ & $3+, 3-$ \\
\hline $\begin{array}{l}\text { Percent White alone not } \\
\text { Hispanic }\end{array}$ & YES, + & $2+$ & $2+$ & $2+$ & $4+$ & $3+, 1-$ \\
\hline Percent Asian alone & YES, + & $1+$ & $2+$ & $2+$ & $2+$ & $3+, 2-$ \\
\hline $\begin{array}{l}\text { Percent American Indian or } \\
\text { Alaska Native alone }\end{array}$ & YES, + & $1+$ & $2+$ & $2+$ & $3+$ & $4+$ \\
\hline $\begin{array}{l}\text { Percent Native Hawaiian or } \\
\text { Pacific I slander alone }\end{array}$ & YES, + & 0 & $1+$ & $2+, 1-$ & $1+$ & $1+, 2-$ \\
\hline $\begin{array}{l}\text { Percent Hispanic or Latino (of } \\
\text { any race) }\end{array}$ & YES, + & $1+$ & $2+$ & $2+$ & $4+$ & $3+, 3-$ \\
\hline Percent under 18 years old & NO & $3+, 1-$ & 0 & $2+$ & $1-$ & $8+, 1-$ \\
\hline Percent 65 years or older & YES, + & $4+$ & $4+$ & $3+$ & $4+$ & $14+, 1-$ \\
\hline $\begin{array}{l}\text { Percent of those } 25 \text { years or } \\
\text { more without a high school } \\
\text { diploma }\end{array}$ & YES, + & $1+$ & $4+$ & $3+$ & $4+$ & $4+$ \\
\hline $\begin{array}{l}\text { Percent of those } 25 \text { years or } \\
\text { more with a bachelor's } \\
\text { degree }\end{array}$ & YES, + & $4+$ & $4+$ & $4+$ & $5+$ & $18+$ \\
\hline $\begin{array}{l}\text { Percent of households that } \\
\text { are married couples }\end{array}$ & YES, + & $3+$ & $4+$ & $4+$ & $5+$ & $3+, 1-$ \\
\hline $\begin{array}{l}\text { Percent of householders that } \\
\text { are single parents }\end{array}$ & YES, + & $3+$ & $3+$ & $3+$ & $3+$ & $5+, 1-$ \\
\hline $\begin{array}{l}\text { Percent of householders living } \\
\text { alone }\end{array}$ & YES, + & $4+$ & $4+$ & $4+$ & $5+$ & $10+$ \\
\hline Percent owner-occupied units & YES, + & $4+$ & $4+$ & $3+$ & $3+$ & $10+$ \\
\hline $\begin{array}{l}\text { Percent of units built in the } \\
\text { previous } 10 \text { years }\end{array}$ & NO & $1+, 1-$ & 1- & 2- & 0 & $2+, 2-$ \\
\hline Percent mobile homes & YES, + & $3+$ & $2+$ & $3+$ & $1-$ & $5+, 1-$ \\
\hline $\begin{array}{l}\text { Percent single-family } \\
\text { detached units }\end{array}$ & YES,- & $2+, 1-$ & 4- & 3- & 4- & $3+, 4-$ \\
\hline $\begin{array}{l}\text { Percent single-family } \\
\text { attached units }\end{array}$ & YES,- & $1+, 1-$ & 3- & 3- & 4- & $1+, 1-$ \\
\hline $\begin{array}{l}\text { Percent of structures with } 20 \\
\text { units or more }\end{array}$ & YES, + & $3+$ & $3+$ & $4+$ & $4+$ & $5+, 1-$ \\
\hline $\begin{array}{l}\text { Percent of occupied units with } \\
1.01 \text { or more persons per } \\
\text { room }\end{array}$ & YES,- & $3-$ & $3-$ & 4- & 4- & $1+, 6-$ \\
\hline $\begin{array}{l}\text { Percent of those } 5 \text { years or } \\
\text { older who do not speak } \\
\text { English "very well" }\end{array}$ & YES,- & $1+, 1-$ & $1-$ & $1+, 2-$ & $1-$ & $1+$ \\
\hline $\begin{array}{l}\text { Percent of households moving } \\
1995 \text { to } 2000\end{array}$ & NO & $1-$ & 0 & 1- & 1- & 3- \\
\hline Percent of those 16 years or & NO & $2+$ & 0 & $1+$ & $2+$ & $1+, 1-$ \\
\hline
\end{tabular}




\begin{tabular}{|c|c|c|c|c|c|c|}
\hline $\begin{array}{l}\text { older in the civilian labor } \\
\text { force who are unemployed }\end{array}$ & & & & & & \\
\hline $\begin{array}{l}\text { Percent below the poverty } \\
\text { level in } 1999\end{array}$ & YES, + & $4+$ & $4+$ & $4+$ & $5+$ & $21+$ \\
\hline Percent foreign born & YES,- & 1- & $1-$ & 1- & $2-$ & $1-$ \\
\hline Units per square mile $(00)$ & YES,- & 4- & 4- & 4- & 5- & $10-$ \\
\hline $\begin{array}{l}\text { Median gross rent (includes } \\
\text { utilities) }(\$ 00)\end{array}$ & YES,- & 4- & 4- & 4- & 5- & 14- \\
\hline $\begin{array}{l}\text { Median housing value of } \\
\text { owner-occupied units }(\$ 0000)\end{array}$ & YES, + & $4+$ & $4+$ & $4+$ & $5+$ & $21+$ \\
\hline $\begin{array}{l}\text { Median household income } \\
(\$ 000)\end{array}$ & YES,- & 4- & 4- & 4- & 4- & 17- \\
\hline $\begin{array}{l}\text { Median travel time of workers } \\
16 \text { years or older not working } \\
\text { at home (minutes) }\end{array}$ & NO & 2- & $1+, 1-$ & $1+, 1-$ & 1- & $1+, 3-$ \\
\hline $\begin{array}{l}\text { Percent below the poverty } \\
\text { level in } 1999 \text { squared }\end{array}$ & YES,- & 4- & 4- & 4- & 4- & $1+, 11-$ \\
\hline \multicolumn{7}{|c|}{ Change from 2000 to 2010 in: } \\
\hline Household population $(00)$ & YES,- & $2-$ & $1-$ & $2-$ & $2-$ & $2+, 5-$ \\
\hline Housing Units (00) & YES, + & $3+$ & $1+$ & $3+$ & $2+$ & $5+$ \\
\hline $\begin{array}{l}\text { Percent Black or African } \\
\text { American alone }\end{array}$ & YES, + & $1+$ & $2+, 1-$ & $1+$ & $1+$ & $1+, 1-$ \\
\hline $\begin{array}{l}\text { Percent White alone not } \\
\text { Hispanic }\end{array}$ & YES, + & $3+$ & $3+$ & $3+$ & $4+$ & $3+, 3-$ \\
\hline Percent Asian alone & NO & 0 & $1+, 1-$ & $1+, 1-$ & 0 & $1+, 2-$ \\
\hline $\begin{array}{l}\text { Percent American Indian or } \\
\text { Alaska Native alone }\end{array}$ & YES, + & 0 & $2+$ & $1+$ & $1+$ & $1+$ \\
\hline $\begin{array}{l}\text { Percent Native Hawaiian or } \\
\text { Pacific I slander alone }\end{array}$ & YES, + & 0 & 0 & 0 & $1+$ & $2+, 2-$ \\
\hline $\begin{array}{l}\text { Percent Hispanic or Latino } \\
\text { (of any race) }\end{array}$ & NO & 0 & $1+$ & 1- & 0 & 4- \\
\hline Percent under 18 years old & YES,- & $2-$ & 3- & 3- & $1+, 3-$ & $1+, 1-$ \\
\hline Percent 65 years or older & YES, + & $4+$ & $2+$ & $3+$ & $4+, 1-$ & $11+$ \\
\hline $\begin{array}{l}\text { Percent of those } 25 \text { years } \\
\text { or more without a high school } \\
\text { diploma }\end{array}$ & NO & 0 & $1+$ & $1+$ & $2+$ & $1+, 1-$ \\
\hline $\begin{array}{l}\text { Percent of those } 25 \text { years } \\
\text { or more with a bachelor's } \\
\text { degree }\end{array}$ & YES, + & $4+$ & $4+$ & $4+$ & $5+$ & $19+$ \\
\hline $\begin{array}{l}\text { Percent of households that } \\
\text { are married couples }\end{array}$ & YES, + & $4+$ & $4+$ & $4+$ & $5+$ & $8+$ \\
\hline $\begin{array}{l}\text { Percent of householders } \\
\text { that are single parents }\end{array}$ & YES, + & $4+$ & $3+$ & $4+$ & $5+$ & $6+$ \\
\hline $\begin{array}{l}\text { Percent of householders } \\
\text { living alone }\end{array}$ & YES, + & $4+$ & $4+$ & $4+$ & $5+$ & $14+$ \\
\hline $\begin{array}{l}\text { Percent owner-occupied } \\
\text { units }\end{array}$ & YES, + & $3+$ & $3+$ & $4+$ & $3+, 1-$ & $5+, 1-$ \\
\hline $\begin{array}{l}\text { Percent of units built in the } \\
\text { previous } 10 \text { years }\end{array}$ & YES, + & $3+$ & $1+$ & $3+$ & $1+$ & $3+, 1-$ \\
\hline Percent mobile homes & NO & $2+$ & $1+, 1-$ & $2+$ & $1+, 1-$ & $3+$ \\
\hline $\begin{array}{l}\text { Percent single-family } \\
\text { detached units }\end{array}$ & NO & $1+, 1-$ & 2- & 1- & 1- & $1+, 3-$ \\
\hline $\begin{array}{l}\text { Percent single-family } \\
\text { attached units }\end{array}$ & YES,- & $1-$ & 3- & $2-$ & $2-$ & 1- \\
\hline
\end{tabular}




\begin{tabular}{|c|c|c|c|c|c|c|}
\hline $\begin{array}{l}\text { Percent of structures with } \\
20 \text { units or more }\end{array}$ & YES, + & $3+$ & $2+$ & $3+$ & $3+$ & $4+, 1-$ \\
\hline $\begin{array}{l}\text { Percent of occupied units } \\
\text { with } 1.01 \text { or more persons } \\
\text { per room }\end{array}$ & YES,-- & 3- & $2-$ & 4- & 3- & 9- \\
\hline $\begin{array}{l}\text { Percent of those } 5 \text { years or } \\
\text { older who do not speak } \\
\text { English "very well" }\end{array}$ & YES,- & $1+, 3-$ & 1- & $1+, 2-$ & $2-$ & $3+, 4-$ \\
\hline $\begin{array}{l}\text { Percent of those } 16 \text { years } \\
\text { or older in the civilian labor } \\
\text { force who are unemployed }\end{array}$ & NO & $1+$ & $1-$ & 0 & 0 & $1+, 1-$ \\
\hline $\begin{array}{l}\text { Percent below the poverty } \\
\text { level in } 1999\end{array}$ & YES, + & $4+$ & $4+$ & $4+$ & $5+$ & $21+$ \\
\hline Percent foreign born & NO & $1+, 1-$ & 0 & 0 & $1+, 1-$ & $2+, 1-$ \\
\hline Units per square mile $(00)$ & YES, + & $3+$ & $1+$ & $3+$ & $2+, 1-$ & $5+, 1-$ \\
\hline $\begin{array}{l}\text { Median gross rent (includes } \\
\text { utilities) }(\$ 00)\end{array}$ & YES,- & 4- & 4- & 4- & $5-$ & $16-$ \\
\hline $\begin{array}{l}\text { Median housing value of } \\
\text { owner-occupied units }(\$ 0000)\end{array}$ & YES, + & $4+$ & $4+$ & $4+$ & $5+$ & $21+$ \\
\hline $\begin{array}{l}\text { Median household income } \\
(\$ 000)\end{array}$ & YES,- & 4- & 4- & 4- & 5- & 21- \\
\hline $\begin{array}{l}\text { Median travel time of } \\
\text { workers } 16 \text { years or older not } \\
\text { working at home (minutes) }\end{array}$ & YES,- & 1- & $1-$ & $1+$ & 2- & $1+, 2-$ \\
\hline
\end{tabular}

SOURCES and NOTES: See Table 1. 
APPENDIX TABLE A.3. Significance and Direction of Effects of Tract Baseline (2000) and Change Characteristics on 2000 to 2010 Change in Census Tract Gini Index, for the 21 Largest Metropolitan Areas

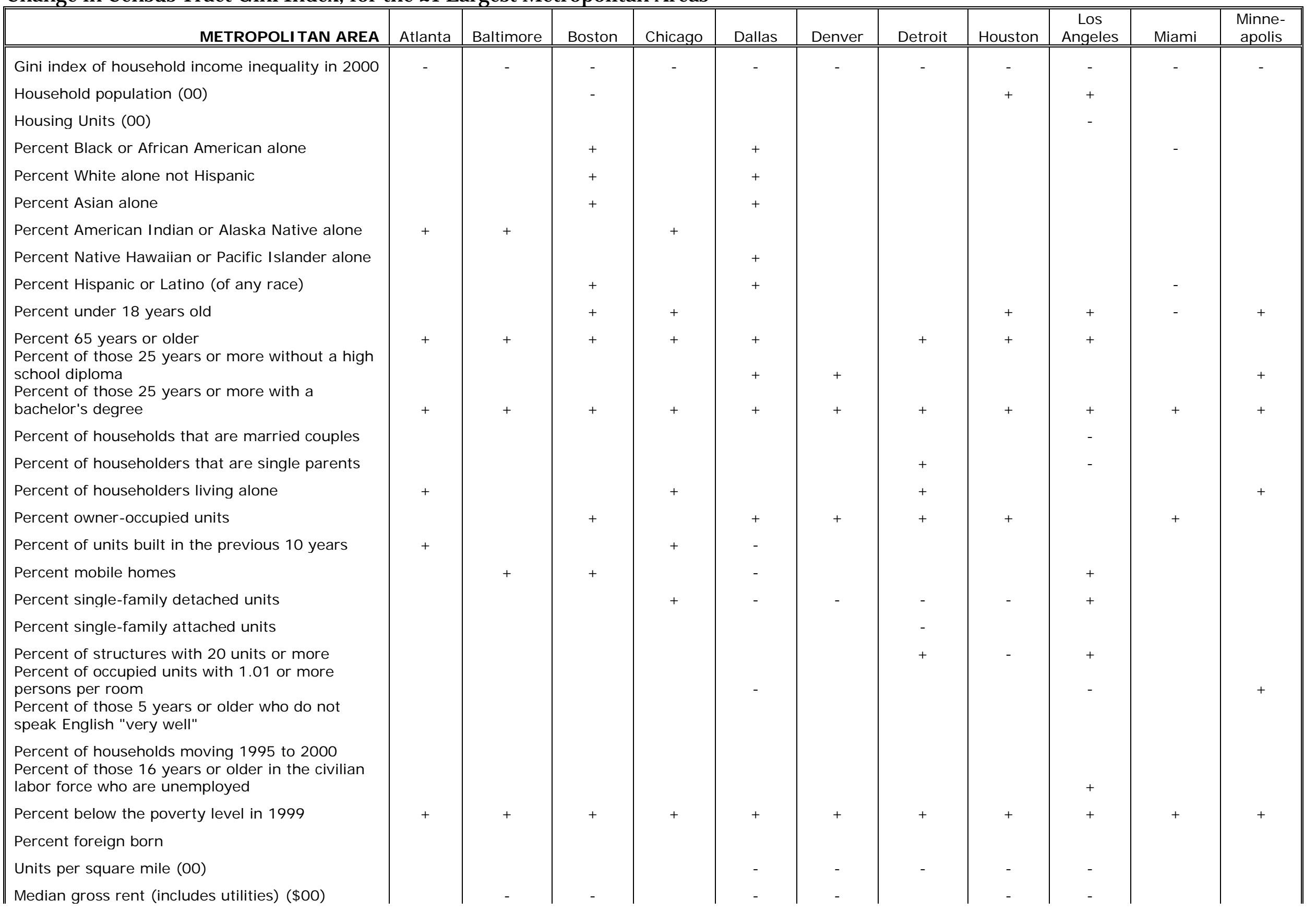


Median housing value of owner-occupied units (\$0000)

Median household income $(\$ 000)$

Median travel time of workers 16 years or older not working at home (minutes)

Percent below the poverty level in 1999 squared

\section{Change from 2000 to 2010 in:}

Household population (00)

Housing Units (00)

Percent Black or African American alone

Percent White alone not Hispanic

Percent Asian alone

Percent American Indian or Alaska Native alone Percent Native Hawaiian or Pacific I slander alone

Percent Hispanic or Latino (of any race)

Percent under 18 years old

Percent 65 years or older

Percent of those 25 years or more without a high school diploma

Percent of those 25 years or more with a bachelor's degree

Percent of households that are married couples Percent of householders that are single parents Percent of householders living alone

Percent owner-occupied units

Percent of units built in the previous 10 years

Percent mobile homes

Percent single-family detached units

Percent single-family attached units

Percent of structures with 20 units or more Percent of occupied units with 1.01 or more persons per room

Percent of those 5 years or older who do not speak English "very well"

Percent of those 16 years or older in the civilian labor force who are unemployed

Percent below the poverty level in 1999

Percent foreign born

Units per square mile $(00)$ 
Median housing value of owner-occupied units (\$0000)

Median household income $(\$ 000)$

Median travel time of workers 16 years or older not working at home (minutes)

Constant

\section{Observations}

$\mathrm{R}^{2}$

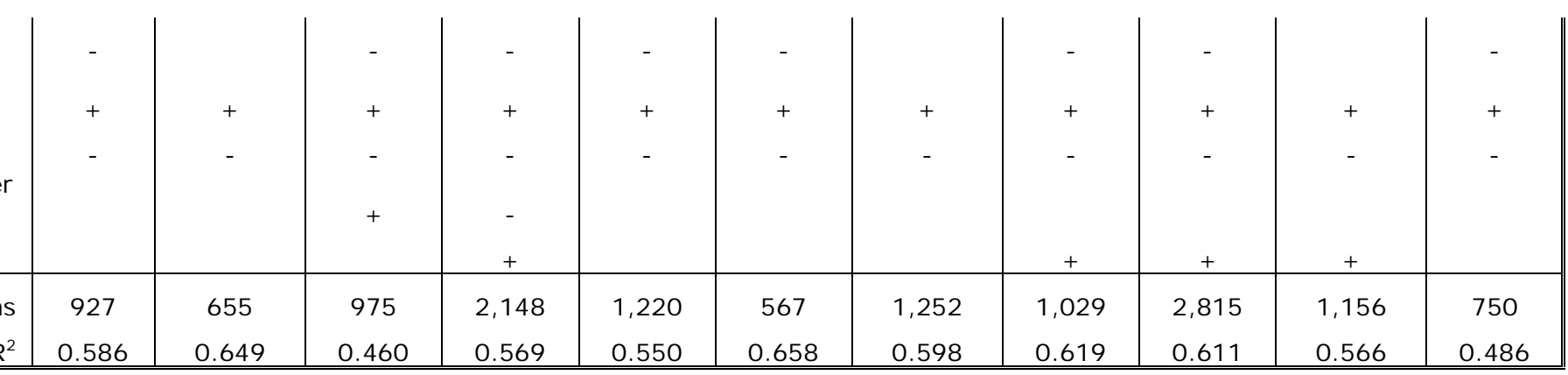

\section{METROPOLITAN AREA \\ Gini index of household income inequality in 2000} Household population (00)

Housing Units (00)

Percent Black or African American alone

Percent White alone not Hispanic

Percent Asian alone

Percent American Indian or Alaska Native alone

Percent Native Hawaiian or Pacific Islander alone

Percent Hispanic or Latino (of any race)

Percent under 18 years old

Percent 65 years or older

Percent of those 25 years or more without a high school diploma

Percent of those 25 years or more with a

bachelor's degree

Percent of households that are married couples

Percent of householders that are single parents

Percent of householders living alone

Percent owner-occupied units

Percent of units built in the previous 10 years

Percent mobile homes

Percent single-family detached units

Percent single-family attached units

Percent of structures with 20 units or more

Percent of occupied units with 1.01 or more

persons per room

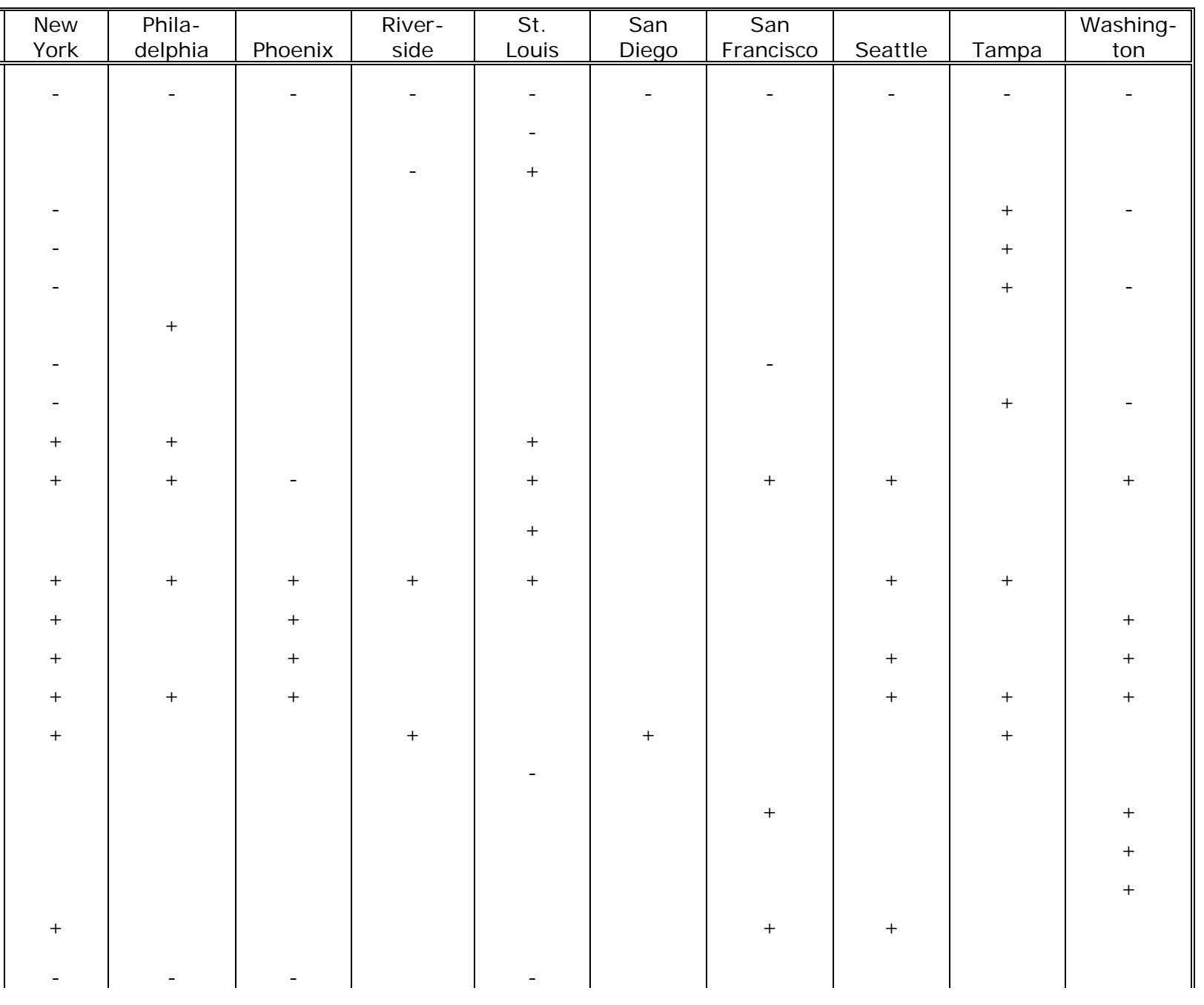


Percent of households moving 1995 to 2000 Percent of those 16 years or older in the civilian labor force who are unemployed

Percent below the poverty level in 1999

Percent foreign born

Units per square mile $(00)$

Median gross rent (includes utilities) $(\$ 00)$ Median housing value of owner-occupied units (\$0000)

Median household income $(\$ 000)$

Median travel time of workers 16 years or older not working at home (minutes)

Percent below the poverty level in 1999 squared

\section{Change from 2000 to 2010 in:}

Household population (00)

Housing Units (00)

Percent Black or African American alone

Percent White alone not Hispanic

Percent Asian alone

Percent American Indian or Alaska Native alone Percent Native Hawaiian or Pacific I slander alone

Percent Hispanic or Latino (of any race)

Percent under 18 years old

Percent 65 years or older

Percent of those 25 years or more without a

high school diploma

Percent of those 25 years or more with a bachelor's degree

Percent of households that are married couples Percent of householders that are single parents Percent of householders living alone

Percent owner-occupied units

Percent of units built in the previous 10 years

Percent mobile homes

Percent single-family detached units

Percent single-family attached units

Percent of structures with 20 units or more 
Percent of occupied units with 1.01 or more persons per room

Percent of those 5 years or older who do not speak English "very well"

Percent of those 16 years or older in the civilian labor force who are unemployed

Percent below the poverty level in 1999 Percent foreign born

Units per square mile $(00)$

Median gross rent (includes utilities) $(\$ 00)$

Median housing value of owner-occupied units (\$0000)

Median household income $(\$ 000)$

Median travel time of workers 16 years or older not working at home (minutes)

Constant

Observations

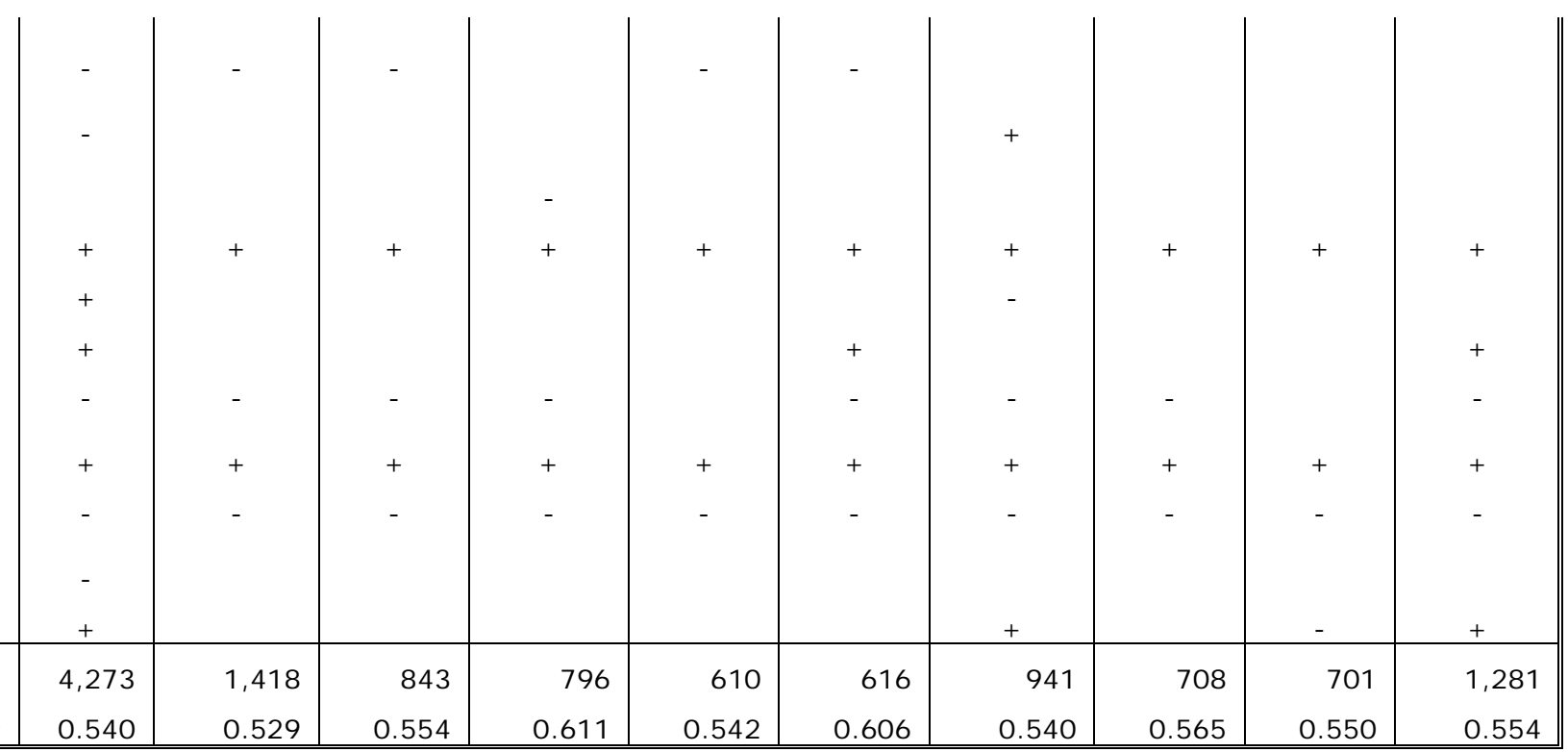

SOURCE and NOTES: See Table 1. Metropolitan areas listed by name of major city rather than the official title. 
